\title{
Ortaokul Öğrencilerinin Bilimsel Sorgulama Görüşleri: Cinsiyet, Sınıf Düzeyi ve Okul Türü Değişkenlerinin İncelenmesi ${ }^{1}$
}

\author{
Middle School Students' Understanding of Scientific Inquiry: An Investigation of \\ Gender, Grade Level and School Type \\ Nihal DOĞAN*, Çiğdem HAN TOSUNOĞLU**, Ferah ÖZER***, Banu AKKAN****
}

· Geliş Tarihi: 19.01.2019 · Kabul Tarihi: 25.09.2019 · Çevrimiçi Yayın Tarihi: 29.09.2019

\begin{abstract}
$\ddot{O} z$
Bilimsel sorgulama (BS), bilim okuryazarı öğrencilerin hedefine ulaşmada en önemli bileşenlerden birisidir. Öğretim programında 'anlayış' ve 'beceri' olarak farklı ifade edilmiş olsa da BS hakkında bilinçli düzeyde görüşlere sahip olan öğrencilerin bu konudaki becerilerinin de daha fazla gelişeceği açıktır. Sorgulama becerilerinin ve anlayışının geliştirilmesi, sorgulamaya dayalı stratejilerin ve sınıf içi uygulamalarının dikkatli bir şekilde planlanmasını ve uygulanmasını gerektirir. Ancak, sorgulamaya dayalı stratejileri planlama ve uygulama öncesinde, uygulamaların kalitesini ve içeriğini planlama adına öğrencilerin bu konudaki hazırbulunuşluluklarını ve görüşlerini inceleyen betimleyici çalışmalara ihtiyaç vardır. $\mathrm{Bu}$ nedenle bu çalışmanın amacı, sosyo ekonomik düzeyleri farklı beş okulda öğrenim gören toplam $n=599$ 5, 6 ve 7. sınıf öğrencilerinin bilimsel sorgulama hakkındaki görüşlerinin betimsel olarak ortaya konulmasıdır. Çalışmanın birincil veri kaynağı, Lederman vd. (2014) tarafından geliştirilen, açık uçlu Bilimsel Sorgulama Hakkında Görüşler Anketi'ne (VASI) verilen öğrencileri yanıtlarıdır. Çalışma sonuçları, ortaokul öğrencilerinin bilimsel sorgulamanın tüm bileşenleri hakkında görüşlerinin yetersiz düzeyde olduğunu göstermiştir. Çalışmanın sonuçları derinlemesine incelendiğinde ise, bilinçli düzeyde görüşlere sahip olan ortaokul öğrencilerinin büyük bir kısmını, özellikle üst-orta sosyoekonomik düzey okulların 6. sınıflarında öğrenim gören öğrencilerin oluşturduğu görülmüştür.
\end{abstract}

Anahtar sözcükler: bilimsel sorgulama, ortaokul öğrencileri, bilim okuryazarı

Atıf:

Doğan, N., Han-Tosunoglu, Ç., Özer, F., \& Akkan, B. (2020). Ortaokul öğrencilerinin bilimsel sorgulama görüşleri: cinsiyet, sınıf düzeyi ve okul türü değişkenlerinin incelenmesi. Pamukkale Üniversitesi Eğitim Fakültesi Dergisi, 49, 162-189. doi: 10.9779/pauefd.515080.

1

* $\quad$ Prof. Dr. Nihal DOĞAN, Bolu Abant İzzet Baysal Üni., Eğitim Fak., Matematik ve Fen Bil.Eğt.Böl. nihaldogan17@gmail.com, http://orcid.org/0000-0003-2225-0812

** Araş. Gör. Dr. Çiğdem HAN TOSUNOĞLU Marmara Üni. Atatürk Eğitim Fak., Matematik ve Fen Bil.Eğt.Böl. cigdemhan@gmail.com , https://orcid.org/0000-0002-5904-656X

*** Araş. Gör. Ferah ÖZER, Boğaziçi Üni., Eğitim Fak., Matematik ve Fen Bilimleri Eğt.Böl. ferah.ozer@boun.edu.tr, https://orcid.org/0000-0001-8621-3522

**** Yük. Lis. Öğr., Bolu Abant İzzet Baysal Üni. Eğitim Bilimleri Ens., bnuakkan@gmail.com , https://orcid.org/0000-0002-1553-9493 


\begin{abstract}
Scientific inquiry (SI) is one of the most important components in achieving the goal of scientifically literate students. Although it is expressed differently in terms of understanding and skill in curricula, it is obvious that students who have adequate understanding about SI will develop the inquiry skills concurrently. Development of inquiry skills and understanding require a careful planning and implementation of inquiry-based strategies and classroom practices. However, before planning and implementing the inquiry based strategies there is a need for descriptive studies that examines the current state of students' views in order to plan the quality and the content of the practices. Therefore, the aim of this study is to descriptively present the SI views of a total of $n=5995^{\text {th }}, 6^{\text {th }}$ and $7^{\text {th }}$ grade students studying at five schools with different socio-economic states in Turkey. The primary data source of the study is the responses of students gathered from the Views About Scientific Inquiry (VASI), that is developed by Lederman et al. (2014), open-ended questionnaire. The results showed that middle school students' views about all aspects of SI are inadequate. Moreover, in depth analysis showed that majority students who holds informed views about SI are the $6^{\text {th }}$ grade students studying at upper-middle socioeconomic state schools.
\end{abstract}

Keywords: scientific inquiry, middle school students, scientific literacy

\title{
Cited:
}

Doğan, N., Han-Tosunoglu, Ç., Özer, F., \& Akkan, B. (2020). Middle school students' understanding of scientific inquiry: An investigation of gender, grade level and school type. Pamukkale Üniversitesi Eğitim Fakültesi Dergisi, 49, 162-189. doi: 10.9779/pauefd.515080. 


\section{Giriş}

Uzun süredir fen eğitiminin odak noktasını oluşturan bilimsel sorgulama, bilim ve teknolojide aktif ve bilinçli karar verebilen, günlük yaşantıları ile ilgili problemlerin çözümünde bilimsel düşünebilen, bilimsel bilgi geliştirmek için bilimsel süreç becerileri ile geleneksel alan bilgisi, yaratıcılık ve eleştirel düşünmenin birleşimini ifade etmektedir (Lederman, 2009). Hem uluslararası hem de ulusal dokümanlarda öğrencilerin bilimsel sorgulama becerilerinin gelişmesi fen eğitiminin önemli amaçlarından biri olarak vurgulanmaktadır (Benchmarks for Science Literacy, AAAS, 1993; A Framework for K-12 Science Education: Practices, Crosscutting Concepts, and Core Ideas, National Research Council [NRC], 2011; Millî Eğitim Bakanlığı, 2018). 21. yüzyıl becerilerinin öneminin ve gelecekte öğrencilerin hayatlarındaki öneminin farkında olarak, Türkiye'de de bilim okuryazarlığıyla birlikte bilimsel sorgulama kavramı fen bilimleri öğretim programında vurgulanmıştır (MEB, 2005; 2013; 2018). Fen bilimleri dersi öğretim programında vurgulanan amaçlardan bazıları aşağıda verilmiştir (MEB, 2018);

'Doğanın keşfedilmesi ve insan-çevre arasındaki ilişkinin anlaşılması sürecinde, bilimsel süreç becerileri ve bilimsel araştırma yaklaşımını benimseyip bu alanlarda karşılaşılan sorunlara çözüm üretmek'

'Günlük yaşam sorunlarına ilişkin sorumluluk alınmasını ve bu sorunları çözmede fen bilimlerine ilişkin bilgi, bilimsel süreç becerileri ve diğer yaşam becerilerinin kullanılmasını sağlamak'

'Bilim insanlarınca bilimsel bilginin nasıl oluşturulduğunu, oluşturulan bu bilginin geçtiği süreçleri ve yeni araştırmalarda nasıl kullanıldığını anlamaya yardımcı olmak'

Dünya'da ve Türkiye'de, fen eğitimi kazanımları ve standartları arasına bilimsel sorgulamanın anlaşılmasının girmesiyle eğitimin temel bileşenlerini oluşturan öğretmen ve öğrencilerin bilimsel sorgulamayı, anlama ve uygulamadaki durumlarının tespit edilmesi önemli bir çalışma alanı haline gelmiştir. Bilimsel sorgulama kavramı uzun yıllardır eğitim dokümanlarında yer alsa da bu alanda yapılan araştırmalar oldukça sınırlıdır. Bu durumun en önemli nedenlerinden biri "bilimsel sorgulama" kavramını ölçmek için kullanılacak, kavramın doğası ile uyumlu, geçerli ve güvenilir bir ölçme aracının uzun bir süre geliştirilmemesi ve bilimsel sorgulama kavramının ölçme sürecinde "bilimin doğası" kavramı ile karıştırılmasıdır (Lederman ve ark., 2014).

Literatürde bilimsel sorgulama anlayışını ortaya çıkaran çalışmalar (Akerson ve Hanuscin, 2007; Lottter, Harwood, Bonner, 2006; 2007; Wee, Fast, Shepardson ve Harbor, 2004) incelendiğinde, öğretmenlerin yetersiz anlayışlara sahip olduğu görülmektedir. Öğrencilerin bilimsel sorgulama anlayışına odaklanan çalışmalara baktığımızda Aydeniz, Baksa ve Skinner'ın (2011) çalışmalarını lise öğrencileri ile yürüttüğü ve bu öğrencilerin bilimsel sorgulamanın temel bileşenlerini öğrenmede zorluklarla karşılaş̧ı̆̆ı görülmektedir. Senler (2015) Amerika Birleşik Devletleri ve Türkiye'deki ortaokul öğrencilerinin bilimsel sorgulama anlayışlarını karşılaştırmak için yaptığı çalışmada VOSI-E enstrümanını kullanmış ve bilimsel sorgulamanın yalnızca dört boyutunu ele almıştır. Yapılan analiz Türkiye'deki ortaokul öğrencilerinin yalnızca "bütün araştırmalarda takip edilen tek bir bilimsel yöntem yoktur" bileşeninde başarı gösterdikleri ve diğer bileşenlerde oldukça yetersiz olduklarını ortaya 
koymaktadır. Lederman ve diğ. (2019) tarafından gerçekleştirilen, aralarında Türkiye'nin de bulunduğu 18 farklı ülkede 7.sınıfta öğrenim gören 2634 öğrencinin bilimsel sorgulama anlayışlarının betimsel olarak araştırıldığı güncel çalışmada, en yüksek örneklem grubuna sahip ülke olan Türkiye'deki 268 7.sınıf öğrencisinin bilimsel sorgulama anlayışlarının sekiz farklı bileşeninde çoğunlukla naif düzeyde yer aldığı tespit edilmiştir. Bununla birlikte, öğrencilerin bilimsel sorgulama anlayışlarının geliştirilmesiyle ilgili Türkiye'de sınırlı sayıda çalışmanın olduğu görülmektedir. Özer ve Doğan (2018) tarafından Türkiye'nin bir ilinde gerçekleştirilen çalışmada, başlangıçta naif seviyesinde yer alan 7.sınıfta öğrenim gören toplam 207 öğrenci deney ve kontrol gruplarına ayrılarak; deney grubu öğrencilerine fen derslerinde 1 yıl boyunca kazanımlara entegre, probleme dayalı öğrenme ve bilim tarihi yaklaşımlarını içeren yenilikçi ders planları uygulanmış ve öğrencilerin bilimsel sorgulama anlayışlarındaki değişim VASI enstrümanı kullanılarak incelenmiştir. Araştırma sonuçları, deney grubu sınıflarında ortak olarak "sorulan soru sorgulama sürecine rehberlik eder", "aynı işlemi yapan bilim insanları aynı sonuçlara ulaşmayabilirler", "sorgulama süreci sonuçlara etki eder", "araştırma sonuçları elde edilen verilerle tutarl olmak zorundadır" bileşenlerinde öğrencilerin görüşlerinde anlamlı farklılıklar oluştuğunu, kontrol gruplarında ise bu bileşenlerde değişiklik olmadığını ortaya koymuştur. Leblebicioğlu, Metin, Çapkınoğlu, Çetin, Doğan ve Schwartz (2017) bilim kampına katılan ortaokul öğrencilerinin (6. ve 7. Sınıf) bilimsel sorgulama anlayışlarını geliştirmeyi amaçladıkları çalışmalarında, başlangıçta genellikle naif ve eklektik olan görüşlerin kampın sonunda bilimsel sorgulamanın belirli bileşenlerinde (Bilimsel araştırmaların hepsi bir soru ile başlar ve her zaman bir hipotez test etmez, bütün araştırmalarda takip edilen tek bir bilimsel yöntem yoktur, açıklamalar, elde edilen veriler ve mevcut bilgilerimizin bir araya gelmesi ile ortaya konulur) pozitif yönde gelişim gösterdiğini; diğer bileşenler açısından aynı performansı ortaya koyamadığını belirtmişlerdir. Bolu (2017) tarafindan gerçekleştirilen çalışmada ise, sosyoekonomik düzeyi düşük bir okulda öğrenim gören 6.sınıf öğrencilerine TUBİTAK destekli araştırma projesinde -"Bilimin Doğasının Öğretimi Konusunda Öğretmenin Mesleki Gelişiminin Süreç Boyunca Desteklenmesi” (BIDOMEG)- geliştirilen bazı etkinlikler modellemeye dayalı öğrenme yaklaşımıyla bir dönem süresince uygulanarak öğrencilerin bilimsel sorgulama hakkındaki görüşlerinin gelişimi izlenmiştir (Doğan ve diğ. 2016). Araştırmada gerçekleştirilen modellemeye dayalı öğrenme yaklaşımı ve BİDOMEG projesinde geliştirilen etkinliklerin etkisi VASI enstrümanı kullanılarak incelenmiştir. Elde edilen sonuçlar, modellemeye dayalı fen öğretiminin Özer ve Doğan (2018) sonuçlarına benzer olarak 6.sınıf öğrencilerinin bilimsel sorgulamanın "sorgulama süreci sonuçlara etki eder" ve "araştırma sonuçları elde edilen verilerle tutarl olmak zorundadır" bileşenleri hakkındaki görüşlerine olumlu etkisi olduğunu göstermiştir. Benzer şekilde, Doğan (2017), fen bilgisi öğretmen adaylarının bilimsel sorgulamayla ilgili anlayışlarını, probleme dayalı öğrenme ve bilim tarihi yaklaşımlarını teknolojik araçlarla da bütünleştirerek hibrit bir yöntem ile geliştirmeyi hedeflediği araştırmasının sonuçlarında ise ögretmen adaylarının bilimsel sorgulama anlayışlarının "Araştırma sonuçları elde edilen verilerle tutarlı olmak zorundadır" bileşeni hariç diğerlerinde pozitif yönde gelişim gösterdiğini rapor etmiştir. Bu sonuçlar Türkiye bağlamında, öğrencilerin ve öğretmen adaylarının bilimsel sorgulama anlayışlarının geliştirilmesine yönelik gerçekleştirilen deneysel/yarı deneysel uygulamaların katılımcıların yaş, eğitim düzeyi, içinde bulundukları sosyo-ekonomik gruplar bağlamında düşünüldüğünde etkili olduğu göstermektedir. 
Yukarıda kısaca özet olarak verilen bilimsel sorgulama ise ilgili güncel alan yazın incelendiğinde, genellikle öğretmenlerin sorgulamaya dayalı öğretim niteliklerinin artırılmasına yönelik deneysel ya da yarı deneysel çalışmalar (Furtak, 2006; Ruiz-Primo \& Furtak, 2006a; Ruiz-Primo \& Furtak, 2006b; Çiğdemoğlu \& Köseoğlu, 2019; Donohue, Buck \& Akerson, 2020), ögretmen adaylarının bilimsel sorgulama hakkındaki görüşlerinin belirlemeye dayalı betimsel çalışmalar (Roth, McGinn \& Bowen, 1998; Haefner \& Zembal-Saul, 2004; Schwarz, 2008; Karışan, Bilican \& Şenler, 2017, Doğan, 2017; Baykar, Yakar \& Liu, 2018) ve üst yaş grup öğrencilerinin bilimsel sorgulama görüşlerini belirlemeye yönelik betimsel çalışmalar (Bell, Blair, Crawford \& Lederman, 2003; Manlove, Lazonder \& Jong, 2006; Gaigher, Lederman \& Lederman, 2014) gerçekleştirildiği görülmektedir. Bu alanda öğretmenlerin sorgulamaya dayalı öğretim niteliklerini arttıracak uygulamaların yanı sıra, mevcut sınırlı sayıdaki çalışmalara (Leblebicioğlu ve diğ.., 2017; Bolu, 2017; Doğan \& Özer (2018) ilave olarak daha fazla sayıda öğrencilerin hali hazırda bu anlayış ve beceriler hakkında sahip olduklar1 görüşleri ortaya koyan (Hamed, Rivero \& Jimenez, 2018; Lederman ve diğ., 2019) ve bu görüşlerin geliştirilmesine yönelik deneysel ve yarı-deneysel çalışmalara da ihtiyaç vardır.

Yukarıda verilen bilgi ve sebepler göz önüne alındığında Türkiye'deki öğrencilerin bilimsel sorgulama ile ilgili görüşleriyle ilgili sınırlı sayıda araştırmanın bulunduğu görülmektedir. Bu çalışmada da öğrencilerin bilimsel sorgulama anlayışlarının tespit edilerek hazırbulunuşluk durumlarının belirlenmesi ve bu görüşlerinin okul türü, sınıf düzeyi ve cinsiyet gibi demografik değişkenler açısından nasıl farklılaştığının ortaya konulması için ortaokul 5., 6. ve 7. sınıf öğrencilerinin bilimsel sorgulama anlayışlarını betimsel olarak incelenmiştir.

\section{Bilimsel Sorgulama Nedir? Fen Eğitiminde Neden Önemlidir?}

Bilimsel sorgulamanın (scientific inquiry) ne anlama geldiği ve bileşenlerinin neler olduğu uzun zamandır tartışılan konulardan biridir. Bilimsel sorgulamanın bileşenlerinin neler olması gerektiği ortaya konulduktan sonra (Schwartz, Lederman ve Lederman, 2004; Crawford, 2014), Lederman vd., 2014) tarafından bilimsel sorgulamayı değerlendirecek bir enstrümanın kavramsal çatısını oluşturmak için literatürdeki bu bileşenler incelenerek okul öncesinden lisans seviyesine kadar fen eğitimi bağlamıyla uyumlu sekiz bileşen bir araya getirilmiştir. Bu bileşenlerin neler olduğu ve ne anlama geldiği aşağıda ayrıntılı olarak açıklanmıştır.

1- Bilimsel araştırmaların hepsi bir soru ile başlar ve her zaman bir hipotez test etmez (BS-1) (Scientific investigations all begin with a question, but do not necessarily test a hypothesis- SI 1)

Bilimsel araştırmalar soru sormayı, yanıtlamayı ve elde edilen yanıtın mevcut bilgiler ile karşılaştırılmasını içerir (National Research Council, 2000). Bilimsel bir araştırmanın gerçekleşmesi için doğal dünya ile ilgili bir soru sorulması gerekir. Diğer taraftan, klasik bilimsel yöntem basamaklarında iddia edildiği gibi bilimsel araştırmaların her zaman bir hipotezle başlamasına ve bu hipotezin test edilmesine gerek yoktur (Lederman vd., 2014).

2- Bütün araştırmalarda takip edilen tek bir bilimsel yöntem yoktur (BS-2) (There is no single set or sequence of steps followed in all investigations-SI 2)

Ders kitaplarında yer alan bilime dair önemli kavram yanılgılarından biri; bilim insanlarının bilimsel bilgi üretim sürecinde kullandığı tek bir bilimsel yöntemin olduğudur. Ancak bilim insanlarının yanıtlamaya çalıştıkları sorulara bağlı olarak farklı 
araştırma yöntemleri kullandıkları bilinmektedir. Öğrencilerin bilimsel sorgulama sürecini etkili şekilde deneyimlemesi için bilimsel bilgi üretiminde farklı yöntemlerin kullanıldığını anlaması gerekmektedir.

3- Sorulan soru sorgulama sürecine rehberlik eder (BS-3) (Inquiry procedures are guided by the questions asked-SI 3)

Bilim insanları aynı sorunun yanıtını farklı sorgulama süreçleri tasarlayarak araştırabilir. Her soruya yanıt verebilen adım adım (yemek tarifi gibi) takip edilmesi önerilen tek bir bilimsel yöntem yoktur. Örneğin; bir paleonteloğun, deneysel araştırma yöntemleri (değişkenleri manipüle ederek) ile sorularına yanıt bulması zor olacağından sorgulama sürecini farklı şekilde tasarlaması gereklidir. Bu örnek bilimsel bir sorunun süreci nasıl yönlendirdiğinin anlaşılması açısından önemlidir.

4- Aynı işlemi yapan bilim insanları aynı sonuçlara ulaşmayabilirler (BS-4) (All scientists performing the same procedures may not get the same resuls-SI 4)

Öğrencilerin bilimsel sorgulama süreci hakkında anlaması gereken diğer bir bileşen bilimsel verilerin farklı şekillerde yorumlanabilmesidir. Bu farklı yorumlamanın temel nedeni, bilim insanlarının teorik altyapıları, delil olarak neye karar verdikleri ve veride yer alan aykırı değerlerle nasıl başa çıktıklarıdır. Bu farklılıklar aynı veriyi inceleyen bilim insanlarının farklı sonuçlara ulaşmasına neden olabilir (Lederman vd., 2014).

5- Sorgulama süreci sonuçlara etki eder (BS-5) (Inquiry procedures can influence the results- SI 5)

Bilimsel araştırmalarda seçilen sorgulama süreci sonunda üretilecek bilimsel açıklamayı doğrudan etkilemektedir. Değişkenlerin tanımlanması, veri toplama yöntemleri, değişkenlerin nasıl ölçüleceği ve analiz edileceği araştırmacının varacağı sonucu etkilemektedir (Lederman vd., 2014).

6- Araştırma sonuçları elde edilen verilerle tutarlı olmak zorundadır (BS-6) (Research conclusions must be consistent with the data collected-SI 6)

Bilimsel bilginin gücü, veriye ve delile dayalı olmasından kaynaklanmaktadır. Bilimsel araştırma sürecinde öne sürülen iddianın geçerliliği, araştırma sorusuna uyumlu seçilen araştırma yöntemi ile desteklenmektedir.

7- Bilimsel veri ile bilimsel kanıt ayn şey değildir (BS-7) (Scientific data are not the same as evidence - SI 7)

Veri, bilimsel araştırma sürecinde yapılan gözlemlerin tamamına verilen isimdir ve farklı yapılarda olabilir (sayılar, resimler, ses kaydı, örnekler vb.). Delil ise veri analiz sürecinin bir ürünüdür. Doğrudan araştırma sorusu ve açıklamalar ile ilişkilidir (Lederman vd. 2014)

8- Açılamalar, elde edilen veriler ve mevcut bilgilerimizin bir araya gelmesi ile ortaya konulur (BS-8) (Explanations are developed from a combination of collected data and what is already known)

Bilimsel açıklamalar, araştırma sonucunda elde edilen bilimsel delillerden üretilmesine rağmen, önceki çalışmaların sonuçları ve mevcut bilimsel bilgiler ile desteklenmelidir. 
Bilim insanları, araştırma sonuçlarının mevcut bilimsel bilgi ile ne zaman ve nasıl farklılaştığı fark edebilmeli ve mevcut bilimsel bilgileri kullanarak verileri nasıl yorumlayacağını tespit edebilmelidir.

Yukarıda açıklanan bu sekiz bileşen Bilimsel Sorgulama Süreci Hakkında Görüşler (Views about Scientific Inquiry, VASI) enstrümanın kavramsal çatısını oluşturmaktadır. Aynı zamanda Lederman ve diğ. (2014) tarafindan bir araya getirilen bu bileşenler Amerika Birleşik Devletleri'nde yayınlanan Yeni Nesil Fen Eğitimi Standartları (Next Generation Science Education Standarts, [NGSS], 2013) içerisinde yer alan "bilimsel pratikler (scientific practices)" ile de örtüşmektedir. Bilimsel pratikler, en genel tanımıyla öğrencilerde bulunması gereken bilimsel sorgulama ve bilimsel süreç becerilerini içerisinde barındıran güncel ve yeni bir kavramsal çerçevedir (Doğan \& Özer 2018).

Bilimsel sorgulamanın bileşenleri ayrıntılarının ortaya konulması beraberinde fen eğitimi açısından bilimsel sorgulamanın öneminin muhakeme edilmesini ve hangi bileşenlerin sınıf içinde neden ya da nasıl öğretilmesi gerektiği üzerine düşünülmesine sebep olmuştur. Osborne (2014), şu an sahip olduğumuz bilgileri nasıl bildiğimiz ya da neden bu bilgilere inandığımızı açıklamadan öğrencilere yalnızca kavramsal bilgiyi/alan bilgisini sunan herhangi bir fen eğitimi anlayışı öğrencilerin bilimin epistemik temellerini açısından eksik kalacağını, Schwartz (2004) ise bilimsel sorgulama bilimsel bilginin üretilmesi, kabul görmesi ve kullanılması dahil bilimsel bilginin gelişim sürecinin özelliklerine odaklanması gerektiğini rapor etmişlerdir. Sınıf içinde gerçekleşen bilimsel sorgulama çalışmalarının öğrenciler açısından kazanımlarının neler olduğunu kısa bir literatür taraması ile ortaya koymaya çalışan Metz (2004), öğrencilerin basit bir şekilde sınıf içinde sorgulama sürecine katılmalarının (araştırma yapması, veri toplaması vb.) bilimin epistemolojisini anlamaları için yeterl olmayacağın rapor etmiştir. Diğer bir ifade ile "bilimsel sorgulama" kavramını, bilimsel sorgulamanın bileşenlerini anlamak olarak, öğrencilerin bilimsel sorgulamayı anlamlandırmadan, bilimsel sorgulamayı deneyimlemesi istenen kazanımlara yeterli düzeyde ulaşmadığını vurgulamaktadır.

Fen eğitiminde bilimsel sorgulama neden önemlidir? Bu soruyu yanıtlayabilmek için bilimsel sorgulama ile bilim okuryazarlığı kavramları arasındaki ilişkinin ortaya konulması gerekmektedir. Bilim okuryazarlı̆̆ı; bilimin ne olduğunu, bilimsel bilginin nasıl üretildiğini anlamak, bilim, teknoloji ve toplumun birinin diğerini nasıl etkilediğini fark edebilmek, bilgisini günlük karar verme mekanizmasında kullanabilmek, bilimin ve teknolojinin değerini toplum içinde takdir edebilmek ve onların sınırlamalarını anlamak olarak tanımlanır (National Research Council, 1996; Roberts, 2008). Bu tanım doğrultusunda bilim okuryazarlığı 21. yüzyıl becerileri arasında en önemli kavramlardan birisidir ve temel bileşenlerini "alan bilgisi", "bilimin doğasl" ve "bilimsel sorgulama" oluşturur (Lederman, 2009). Bilimsel sorgulama, bilim okuryazarı birey yetiştirilmesi amacına ulaşmada en önemli bileşenlerden birisidir ve uluslararası reform dokümanlarında 'anlayış' ve 'beceri' olarak ifade edilmesi gerektiği vurgulanmaktadır (NGSS, 2013). Fen öğretim programları dökümanlarında, öğrencilerin, bilimsel bilgi üretim sürecinin nasıl gerçekleştiğini anlamaları" ile "bilimsel bilgi üretim sürecini gerçekleştirecek temel becerileri kazanmaları" hedefleri farklı şekilde sunulmuş olsa da beceri ve anlayış arasındaki ilişki perspektifinden bakıldığında bilimsel sorgulama ile ilgili bilinçli görüşlere sahip olan öğrencilerin bu konudaki becerilerinin daha fazla gelişeceği açıkça görülmektedir. 2018 Fen Bilgisi Dersi öğretim programı (MEB, 2018)ve giriş bölümünde birkaç 
örneği verilen amaçlar incelendiğinde, bilimsel sorgulamanın öğrencilere hem 'anlayış' hem 'beceri' olarak kazandırılması beklendiği görülmektedir.

\section{Yöntem}

$\mathrm{Bu}$ çalışmada geniş bir evren ve örneklem içerisinde, evren hakkında genel bir durum değerlendirmesi ve yargıya varma amacıyla gerçekleştirileceği belirtilen (Karasar, 2018) betimsel (tarama) çalışması (descriptive studies) ortaokul öğrencileriyle gerçekleştirilmiştir. Çalışma kapsamında ortaokul öğrencilerinin bilimsel sorgulama anlayışları betimsel olarak cinsiyet, sınıf düzeyi ve okul türü alt değişkenlerine göre araştırılmıştır.

Araştırmanın verileri, Lederman ve diğerleri tarafından 2014 yılında geliştirilen Bilimsel Sorgulamaya İlişkin Görüşler Anketi (Views about Scientific Inquiry Questionnaire-VASI) kullanılmıştır. Anketin Türkçe'ye uyarlaması ve adaptasyonu Han-Tosunoglu, Dogan, Yalaki, Cakir ve İrez (2017) tarafindan gerçekleştirilmiş; anketin ortaokul öğrencilerine uygulanabilmesi için gerekli izinler hem yazarlardan hem de ilgili etik kurullardan alınmıştır. Bilimsel Sorgulamaya İlişkin Görüşler Anketi yedi alt olmak üzere 7 ana açık uçlu sorudan oluşmaktadır. Öğrencilere anketler fen bilgisi öğretmenleri ve yazarlar tarafından uygulanmıştır. Anket uygulama süresi ortalama $30 \mathrm{dk}$ olarak belirlenmiştir. Ankette yer alan her bir soru ve alt soru Tablo 1'de de gösterildiği üzere, bir bilimsel sorgulama bileşeni ölçmeyi hedeflemektedir (Tablo 1).

Tablo 1. Bilimsel sorgulamaya ilişkin görüş̧ anketindeki soruların ölçmeyi hedeflediği bilimsel sorgulama bileșenleri

\begin{tabular}{lc}
\hline \multicolumn{1}{c}{ Bilimsel Sorgulama Bileşenleri } & Soru No \\
\hline $\begin{array}{l}\text { Bilimsel araştırmaların hepsi bir soru ile başlar ve her zaman bir hipotez test etmez } \\
\text { (Begins with a question) }\end{array}$ & 1a, 1b,2 \\
$\begin{array}{l}\text { Bütün araştırmalarda takip edilen tek bir bilimsel yöntem yoktur (Multiple methods) } \\
\begin{array}{l}\text { Aynı işlemi yapan bilim insanları aynı sonuçlara ulaşmayabilirler (Procedures may not } \\
\text { yield the same results) }\end{array}\end{array}$ & 1b,1c \\
$\begin{array}{l}\text { Sorgulama işlemi sonuçlara etki eder (Procedures influence results) } \\
\text { Bilimsel veri ile bilimsel kanıt aynı şey değildir (Data are not the same as evidence) }\end{array}$ & $3 \mathrm{~b}$ \\
$\begin{array}{l}\text { Sorulan soru sorgulama işlemine rehberlik eder (Procedures are guided by the } \\
\text { question asked) }\end{array}$ & 4 \\
$\begin{array}{l}\text { Araştırma sonuçları toplanan verilerle tutarlı olmak zorundadır (Consistent with data } \\
\text { collected) } \\
\begin{array}{l}\text { Çkarımlar, toplanan verilere ve önceden bilinenlere dayanılarak yapılır (Explanations } \\
\text { are developed from data and already known conclusions) }\end{array}\end{array}$ & 5 \\
\hline
\end{tabular}

\section{Çalışma Grubu}

Çalışmaya, 2016-2017 Eğitim Öğretim yılında Türkiye'nin Batı Karadeniz Bölgesi’nin bir ilinde bulunan 5 farklı ortaokulunda (4 devlet okulu, 1 özel okul) öğrenim gören toplam 599 (315 kız, 284 erkek) 5., 6. ve 7.sınıf öğrencisi katılmıştır. "8.sınıf öğrencileri çalışmaya dahil 
edilememiştir. $\mathrm{Bu}$ durumun temel nedeni ise okul idarecileri ve öğretmenlerinin merkezi sınavlara hazırlık sürecinde olan 8.sınıf öğrencilerinin farklı uygulamalara katılımları konusunda gönüllü ve destek olamayacaklarını önceden çalışma ekibine bildirmiş olmalarıdır". Anketler öğrencilere 2016-2017 eğitim-öğretim yılının ilk döneminde uygulanmıştır. Öğrencilerin anketlere verdikleri yazılı yanıtları derinlemesine incelemek ve anlaşılamayan cevapları açıklığa kavuşturmak amacıyla toplam öğrenci sayısının \%10'u rastgele seçilerek (toplam 59 öğrenci) yarı yapılandırılmış görüşmeler gerçekleştirilmiştir. Öğrenci ve okul isimlerinin gizli tutulması amaciyla okul türü A-B-C-D-E, cinsiyet K-E ve sınıf seviyesi 5-6-7 olarak kodlanmıştır. Örneğin; Öğrenci: B.K.6.21 kodunun nasıl oluşturulduğu sırasıyla B (okul türü), K (Kız), 6 (6. sınıf), 21 (21 numaralı öğrenci) şeklindedir.

Tablo 2.Çalışmaya katılan öğrencilerin cinsiyet, sınıf seviyesi ve okul türüne göre sayısal dağılımları

\section{OKUL TÜRÜ}

\begin{tabular}{llllll} 
Cinsiyet & A Okulu* & B Okulu* & C Okulu** & D Okulu** & E Okulu*** \\
\hline Kız & 102 & 45 & 85 & 57 & 26 \\
Erkek & 103 & 51 & 48 & 64 & 18 \\
\hline
\end{tabular}

* A ve B okulu: Orta sosyo-ekonomik düzey

** C ve D okulu :Üst sosyo-ekonomik düzey

***E okulu: Alt sosyo-ekonomik düzey

\section{Verilerin Analizi}

Anket ve görüşme yoluyla elde edilen veriler, nitel veri analiz yöntemlerinden içerik analiz tekniği kullanılarak analiz edilmiştir. İçerik analizi sözel, yazılı ve diğer materyallerin nesnel ve sistematik olarak incelenmesine olanak tanıyan bilimsel bir yaklaşımdır (Tavşancıl ve Aslan, 2001). İçerik analizi; verilerin tanımlanması ve verilerin içinde gizlenen bilgilerin ortaya çıkarılmasını amaçlamaktadır. İçerik analizi, verilerin kodlanması, temaların bulunması, kodların ve temaların düzenlenmesi ve bulguların tanımlanması ve yorumlanması olmak üzere dört aşamada gerçekleştirilir (Yıldırım \& Şimşek, 2006).

Roberts, Priest, Traynor (2006), herhangi bir olayın farklı araştırmacılar tarafindan aynı anda incelenmesiyle tutarlı, anlaşılır ve güncel olma durumunun artırılacağını belirtmiştir. Bu amaçla verilerin analizi üç araştırmacı tarafından gerçekleştirilmiştir. Araştırmacılar ilk olarak rastgele seçmiş oldukları beş anketi birlikte kodlayarak, kodlamada nasıl bir yol izleyeceklerini belirlemişlerdir. Ardından, 15 anketi bireysel olarak kodlamışlar ve sonrasında bir araya gelip fikir ayrılı̆̆ı olan kodlamalar üzerinde uzlaşma sağlamışlardır. İlk kodlamada kodlayıcılar arası uyum yüzdesi (inter-rater reliability) \%95 olarak hesaplanmıştır. Geriye kalan 584 anket araştırmacılar arasında paylaşılmış ve tüm bileşenlerde sorular bütünsel bir bakış açısıyla ele alınmış ve değerlendirilmiştir.

Anketi geliştiren Lederman ve diğerlerinin (2014) görüşmeler için önerdiği aralık katılımcıların yaklaşık \%10-15'ini kapsamaktadır. Öğrencilerle yapılan bireysel görüşmelerde; soruların bazılarına çok açıklayıcı yanıt vermekten kaçındıkları, zaman zaman utandıkları, görüşmeye çok fazla katılmadıkları ve detaylı açıklamalar yapmadıkları tespit edilmiştir. Bu nedenle üçüncü 
görüşmeden itibaren öğrenciler üç ya da dörder kişilik gruplar halinde görüşmeler ses kayıtları alınarak görüşmeler gerçekleştirilmiştir. Her öğrencinin görüşme transkripti ve anket sorularına verdiği cevaplar araştırmacılar tarafından birlikte incelenerek nitel analizleri gerçekleştirilmiştir.

Öğrencilerin bilimsel sorgulamaya ilişkin görüşleri, Lederman ve diğerlerinin (2014) çalışmalarında değerlendirmeler için önerdikleri derecelendirme ölçütleri (rubrikler) 1şığında değerlendirilerek "naif”, "klsmen bilinçli" ve "bilinçli" olarak üç farklı kategoride kodlanmıştır (Lederman vd. 2014; Gaigher, Lederman \& Lederman, 2014). Bu kategorizasyondan bazı örnekler aşağıda sunulmuştur.

Bilinçli;

Evet diyene kattliyorum. Çünkü bilimsel bir olay, soru olmadan bilimsel araşttrma yaparsak sonucunda nereye varacağımızı neyin cevabını aradı̆̆ımızı bilemeyiz (Anket 1. Soru, Öğrenci: B.K.6.21).

Evet yoktur. Çünkü araştırma yaparken bir yöntem takip edilmez yani birden fazla yöntem olabilir (Anket 2. Soru, Öğrenci: A.K.6.3).

Bence bitkiler güneşte uzar. Ama tabloya göre cevaplarsak B olarak görünüyor (Anket 6. Soru Öğrenci: E.K.6.9).

Kısmen Bilinçli;

Evet. Ĕger bir yöntem kullanırsak bu olayın farkl nedenlerini araşttramaz, az bilgi toplamış oluruz-Yukarıda ki metinden örnek verebilirim. Bence hem yediği şeylerden araşttrıp diğer yönden de kuşların farklı yaşadığı olaylardan mi gaga şeklinin değistiğ̈ini araştırırım. Böylece birden fazla yöntem uygulamış olurum. İkisi de farklı sonuçlar doğursa da ikisi de bunların üzerinde çalışllıp denendiği için bilimsel olarak kalırlar (Anket 2. Soru, Öğrenci: B.K.6.21).

Naif;

Hayır deney değildir çünkü deney genellikle laboratuvarlarda yapılan bir araştırmadır (Anket 1. Soru, Öğrenci) A.K.5.10.

Bence bilimsel değil. Gözlem yapmıs. Kuşları gözlemiştir (Anket 1. Soru, Öğrenci: A.E.7.3).

A çünkü güneş ışlğı bitkilerin uzaması için gerekli enerjiyi sağlar (Anket 6. Soru, Öğrenci:

D.E.5.6).

Kodlama süreci istatistiksel veri analizi programıyla gerçekleştirilmiş ve veriler betimsel istatistik yöntemleriyle analiz edilerek, ilgili bileşen, cinsiyet, okul türü ve sınıf düzeyine göre tablolar oluşturulmuştur. Ayrıca kategorik veri değişkenleri arasındaki ilişkilerin anlamlılığı Pearson Ki-Kare Testi (chi-square) yardımıyla gerçekleştirilmiştir. Elde edilen değerler, betimsel istatistik tablolarına eklenerek, değişkenlerin öğrenci görüşleri üzerindeki etkisi arasındaki ilişkilerin istatistiksel anlamlılığı değerlendirilmiştir.

\section{Bulgular}

Bilimsel Sorgulamayla İlgili Görüşler Anketine ortaokul öğrencilerinin verdiği yanıtlar cinsiyet, sınıf düzeyi ve okul türü değişkenlerine göre analiz edilmiştir. Araştırma sonucunda elde edilen bulgular tablo ve grafiklerle ayrıntılı olarak aşağıda verilmiştir. 
1. Ortaokul ögrencilerin Bilimsel Sorgulama İle İlgili Görüşlerinin (Bilinçli, Kısmen Bilinçli ve Naif kategori analizi) Yüzde Değerleri

Araştırmaya katılan ortaokul öğrencilerinin bilimsel sorgulama ile ilgili anlayışları bilinçli, kısmen bilinçli ve naif olarak kategorize edilerek analizleri yapılmış ve yüzde değerleri Tablo 3'de verilmiştir.

Tablo 3 incelendiğinde öğrencilerin büyük bir çoğunluğunun Naif düzeyde anlayışla sahip olduğu görülmektedir. Naif anlayış düzeyinin en yüksek olduğu oran "Çıkarımlar, toplanan verilere ve önceden bilinenlere dayanılarak yapılır $(\% 67,3)$ bileşeninde tespit edilmiştir. Naif düzeyde bulunan öğrencilerin yüzdelerinin genellikle \%50 değerinin üzerinde olduğu tespit edilirken bilinçli görüşlerin "Araştırma sonuçları toplanan verilerle tutarlı olmak zorundadır" bileşeninde en yüksek düzeyde $(\% 17,7)$ olduğu belirlenmiştir.

Tablo 3. Ortaokul Öğrencilerinin Bilimsel Sorgulama İle İlgili Bilinçli, Kısmen Bilinçli ve Naif Görüşlerinin Yüzde Değerleri

\begin{tabular}{|c|c|c|c|c|}
\hline $\begin{array}{l}\text { Soru } \\
\text { No }\end{array}$ & Bileşenler & $\begin{array}{l}\text { Bilinçli } \\
\%\end{array}$ & $\begin{array}{l}\text { Kısmen } \\
\text { Bilinçli } \\
\%\end{array}$ & Naif\% \\
\hline $1 \mathrm{a}, 1 \mathrm{~b}, 2$ & $\begin{array}{l}\text { Bilimsel arasstırmaların hepsi bir soru ile başlar ve her zaman bir } \\
\text { hipotez test etmez (Begins with a question) }\end{array}$ & 5,3 & 39,2 & 55,4 \\
\hline $1 \mathrm{~b}, 1 \mathrm{c}$ & $\begin{array}{l}\text { Bütün araştırmalarda takip edilen tek bir bilimsel yöntem yoktur } \\
\text { (Multiple methods) }\end{array}$ & 3,5 & 46,4 & 50,1 \\
\hline $3 a$ & $\begin{array}{l}\text { Aynı işlemi yapan bilim insanları aynı sonuçlara ulaşmayabilirler } \\
\text { (Procedures may not yield the same results) }\end{array}$ & 15,2 & 29,9 & 54,9 \\
\hline $3 b$ & $\begin{array}{l}\text { Sorgulama işlemi sonuçlara etki eder (Procedures influence } \\
\text { results) }\end{array}$ & 14 & 36,7 & 49,2 \\
\hline 4 & $\begin{array}{l}\text { Bilimsel veri ile bilimsel kanıt aynı şey değildir (Data are not the } \\
\text { same as evidence) }\end{array}$ & 11,5 & 46,2 & 42,2 \\
\hline 5 & $\begin{array}{l}\text { Sorulan soru sorgulama işlemine rehberlik eder (Procedures are } \\
\text { guided by the question asked) }\end{array}$ & 4,7 & 29,4 & 65,9 \\
\hline 6 & $\begin{array}{l}\text { Araştırma sonuçları toplanan verilerle tutarlı olmak zorundadır } \\
\text { (Consistent with data collected.) }\end{array}$ & 17,7 & 27 & 56,3 \\
\hline 7 & $\begin{array}{l}\text { Çıkarımlar, toplanan verilere ve önceden bilinenlere dayanılarak } \\
\text { yapılır (Explanations are developed from data and already known } \\
\text { conclusions) }\end{array}$ & 3,2 & 29,5 & 67,3 \\
\hline
\end{tabular}

Tablodan da çok açık olarak görüldüğü üzere ortaokul öğrencilerinin her seviyede bilinçli düzeyde anlayışa sahip olma oranı \%20'nin üzerinde tespit edilmemiştir.

\section{Ortaokul Öğrencilerinin Bilimsel Sorgulama Anlayışlarının Cinsiyete Göre İncelenmesi}

Araştırmaya katılan ortaokul öğrencilerinin bilimsel sorgulama ile ilgili anlayışları bilinçli, kısmen bilinçli ve naif olarak cinsiyete göre kategorizasyonu yapılmış ve yüzde değerleri Tablo 4 'de verilmiştir. 
Tablo 4. Ortaokul Öğrencilerinin Bilimsel Sorgulama İle İlgili Bilinçli, Kısmen Bilinçli ve Naif Görüşlerinin Cinsiyete Göre Yüzde Değerleri

\begin{tabular}{|c|c|c|c|c|c|c|}
\hline Bilimsel Sorgulama Bileşenleri & Cinsiyet & Bilinçli \% & $\begin{array}{l}\text { Kısmen } \\
\text { Bilinçli \% }\end{array}$ & Naif \% & $\begin{array}{l}\text { Ki-kare-1 } \\
\mathrm{P}_{1} \\
\text { Değeri* }\end{array}$ & $\begin{array}{l}\text { Ki-kare-2 } \\
\mathrm{P}_{2} \\
\text { Değeri** }\end{array}$ \\
\hline \multirow{2}{*}{$\begin{array}{l}\text { Bilimsel araştırmaların hepsi bir soru } \\
\text { ile başlar ve her zaman bir hipotez test } \\
\text { etmez (Begins with a question) }\end{array}$} & $\mathrm{K} 1 \mathrm{z}$ & 7 & 43,2 & 49,8 & \multirow{2}{*}{0,008} & \multirow[t]{2}{*}{0,24} \\
\hline & Erkek & 3,5 & 34,9 & 61,6 & & \\
\hline \multirow{2}{*}{$\begin{array}{l}\text { Bütün araştırmalarda takip edilen tek } \\
\text { bir bilimsel yöntem yoktur (Multiple } \\
\text { methods) }\end{array}$} & $\mathrm{K}_{1 \mathrm{Z}}$ & 5,4 & 49,5 & 45,1 & \multirow{2}{*}{0,003} & \multirow[t]{2}{*}{0,026} \\
\hline & Erkek & 1,4 & 43 & 55,6 & & \\
\hline \multirow{2}{*}{$\begin{array}{l}\text { Aynı işlemi yapan bilim insanları aynı } \\
\text { sonuçlara ulaşmayabilirler } \\
\text { (Procedures may not yield the same } \\
\text { results) }\end{array}$} & Kiz & 5,7 & 33,3 & 61 & \multirow{2}{*}{0,023} & \multirow[t]{2}{*}{0,642} \\
\hline & Erkek & 3,5 & 25 & 71,5 & & \\
\hline \multirow{2}{*}{$\begin{array}{l}\text { Sorgulama işlemi sonuçlara etki eder } \\
\text { (Procedures influence results) }\end{array}$} & $\mathrm{K}_{1 \mathrm{z}}$ & 21 & 33 & 46 & \multirow{2}{*}{0,000} & \multirow[t]{2}{*}{0,02} \\
\hline & Erkek & 8,8 & 26,4 & 64,8 & & \\
\hline \multirow{2}{*}{$\begin{array}{l}\text { Bilimsel veri ile bilimsel kanıt aynı } \\
\text { şey değildir (Data are not the same as } \\
\text { evidence) }\end{array}$} & $\mathrm{K}_{1 \mathrm{Z}}$ & 20 & 39,4 & 40,6 & \multirow{2}{*}{0,000} & \multirow[t]{2}{*}{0,003} \\
\hline & Erkek & 7,4 & 33,8 & 58,8 & & \\
\hline \multirow{2}{*}{$\begin{array}{l}\text { Sorulan soru sorgulama işlemine } \\
\text { rehberlik eder (Procedures are guided } \\
\text { by the question asked) }\end{array}$} & $\mathrm{K}_{1 \mathrm{z}}$ & 21,6 & 23,2 & 55,2 & \multirow{2}{*}{0,019} & 0,006 \\
\hline & Erkek & 13,4 & 29,2 & 57,4 & & \\
\hline \multirow{2}{*}{$\begin{array}{l}\text { Araştırma sonuçları toplanan verilerle } \\
\text { tutarlı olmak zorundadır (Consistent } \\
\text { with data collected.) }\end{array}$} & $\mathrm{K}_{1 \mathrm{Z}}$ & 17,1 & 48,9 & 34 & \multirow{2}{*}{0,000} & 0,001 \\
\hline & Erkek & 5,3 & 43,3 & 51,4 & & \\
\hline \multirow{2}{*}{$\begin{array}{l}\text { Çıkarımlar, toplanan verilere ve } \\
\text { önceden bilinenlere dayanılarak } \\
\text { yapılır (Explanations are developed } \\
\text { from data and already known } \\
\text { conclusions) }\end{array}$} & K1z & 4,4 & 31,7 & 63,8 & \multirow[b]{2}{*}{0,059} & \multirow[t]{2}{*}{0,149} \\
\hline & Erkek & 1,8 & 27,1 & 71,1 & & \\
\hline
\end{tabular}

* $\mathrm{P}_{1}$ değeri: 3 grupta yer alan öğrenciler için hesaplanan tekrarlanan Ki-Kare Pearson anlamlılık değeri

** $\mathrm{P}_{2}$ değeri: Naif grubunda bulunan öğrenciler çıkarıldıktan sonra tekrarlanan Ki-kare Pearson anlamlılık değeri

Tablo 4 incelendiğinde $\mathrm{p}>0.05$ olduğundan dolayı kız ve erkek öğrenciler arasında cinsiyete göre istatistiksel olarak anlamlı bir fark olduğu söylenebilir.

Erkek öğrencilerin tüm bileşenlerde kız öğrencilere göre naif düzeyde anlayışa sahip olduğu görülmektedir. Erkek öğrencilerde naif anlayış düzeyinin en yüksek olduğu oran "Çıkarımlar, toplanan verilere ve önceden bilinenlere dayanılarak yapılır $(\% 71,1)$ bileşeninde tespit edilmiştir.

Erkek öğrencilerde naif düzeyde bulunan öğrencilerin yüzdelerinin genellikle \%50 değerinin üzerinde olduğu tespit edilirken bilinçli görüşlerin "Sorulan soru sorgulama işlemine rehberlik 
eder" (\%13,4) olduğu belirlenmiştir. Erkek öğrencilerden "Naif” kategoride verilen cevaplardan bir örnek aşağıdaki gibidir:

-B grubudur. Çünkü deneyi daha detayll yapmıștır (Öğrenci: E.E.5.3).

Kız öğrencilerde ise naif anlayış düzeyinin en yüksek olduğu oran "Çıkarımlar, toplanan verilere ve önceden bilinenlere dayanılarak yapılır" $(\% 63,8)$ bileşeninde tespit edilmiştir. Buna göre kız ve erkek öğrenciler arasında en çok naif anlayış "Çıkarımlar, toplanan verilere ve önceden bilinenlere dayanılarak yapılır” bileșeni olarak bulunmuştur.

Kız öğrencilerde bilinçli görüş "Sorulan soru sorgulama işlemine rehberlik eder" (\%21,6) olduğu bulunmuş̧tur. Kız öğrencilerden "Bilinçli" kategoride verilen cevaplardan bir örnek aşağıdaki gibidir:

B şılkkıdır. Tabloda hiç ışık verilmemiş ve $25 \mathrm{~cm}$ uzamıştır. Ama ışık verildikçe küçülmüştür.(Öğrenci: B.K.6.11.)Tablodan da çok açık olarak görüldüğü üzere ortaokul öğrencilerinin cinsiyet farklılığına göre kız öğrencilerin daha bilinçli olduğu fakat bilinçli düzeyde anlayışa sahip olma oranının \%21,6 ile sınırlı kaldığ tespit edilmiştir. Bu oranın çok düşük olduğu görülmektedir.

\section{Ortaokul Öğrencilerinin Bilimsel Sorgulama Anlayışlarının Okul Türüne Göre İncelenmesi}

Araştırmaya katılan ortaokul öğrencilerinin bilimsel sorgulama ile ilgili anlayışları bilinçli, kısmen bilinçli ve naif olarak okula göre kategorizasyonu yapılmış ve yüzde değerleri Tablo 5 'de verilmiştir

Tablo 5 incelendiğinde tüm bileşenlerde genel olarak "E" olarak kodlanan okulun diğer okullara göre naif düzeyde anlayışa sahip olduğu görülmektedir. "B" olarak kodlanan okulun ise diğer okullara göre bilinçli anlayışa sahip olduğu belirlenmiştir. Naif anlayış düzeyinin en yüksek olduğu oran "Çıkarımlar, toplanan verilere ve önceden bilinenlere dayanılarak yapılır" (\%83,5) bileşeninde tespit edilmiştir.

Naif düzeyde bulunan öğrenci yüzdelerinin genellikle \%50 değerinin üzerinde olduğu tespit edilirken bilinçli görüşlerin "Sorulan soru sorgulama işlemine rehberlik eder" (\%30,2) olduğu belirlenmiştir. "Bilinçli” kategoride cevap veren öğrencilerden bir örnek aşağıda ki gibidir:

-Hayır, bilim insanları aynı süreçleri takip etse de insanların düşünceleri farklıdır (Öğrenci: B.K.6.20). 
Tablo 5. Ortaokul Öğrencilerinin Bilimsel Sorgulama İle İlgili Bilinçli, Kısmen Bilinçli ve Naif Görüşlerinin Okula Göre Yüzde Değerleri

\section{Okul İsimleri}

\begin{tabular}{|c|c|c|c|c|c|c|c|c|}
\hline Temalar & & A & B & $\mathrm{C}$ & D & $\mathbf{E}$ & Pearson Ki & $\begin{array}{l}\text { Pearson Ki- } \\
\text { Kare-2 }\end{array}$ \\
\hline & & $\%$ & $\%$ & $\%$ & $\%$ & $\%$ & & \\
\hline Bilimsel araştırmaların hepsi & Bilinçli & 2 & 17,7 & 4,5 & 4,1 & 0 & & \\
\hline $\begin{array}{l}\text { bir soru le başlar ve her } \\
\text { zaman bir hipotez test etmez }\end{array}$ & $\begin{array}{l}\text { Kısmen } \\
\text { Bilinçli }\end{array}$ & 29,3 & 42,7 & 33,1 & 52,9 & 59,1 & 0 & 0 \\
\hline & Naif & 68,8 & 39,6 & 62,4 & 43 & 40,9 & & \\
\hline Bütün araştırmalarda takip & Bilinçli & 2,4 & 10,4 & 3 & 1,7 & 0 & & \\
\hline yöntem yoktur ( Multiple & $\begin{array}{l}\text { Kısmen } \\
\text { Bilinçli }\end{array}$ & 30,2 & 63,5 & 33,1 & 71,9 & 54,5 & 0 & ,033 \\
\hline & Naif & 67,3 & 26 & 63,9 & 26,4 & 45,5 & & \\
\hline Aynı işlemi yapan bilim & Bilinçli & 1 & 10,4 & 9 & 2,5 & 2,3 & & \\
\hline unsanları aynı sonuçlara & $\begin{array}{l}\text { Kismen } \\
\text { Bilinçli }\end{array}$ & 33,7 & 18,8 & 33,1 & 30,6 & 18,2 & & \\
\hline $\begin{array}{l}\text { may not yierd the same } \\
\text { results) }\end{array}$ & Naif & 65,4 & 70,8 & 57,9 & 66,9 & 79,5 & 0 & 0 \\
\hline $\begin{array}{l}\text { Sorgulama işlemi sonuçlara } \\
\text { etki eder (Procedures }\end{array}$ & Bilinçli & 4,4 & 21,9 & 22,6 & 22,3 & 9,1 & & \\
\hline $\begin{array}{l}\text { etk1 eder (Procedures } \\
\text { influence results) }\end{array}$ & $\begin{array}{l}\text { Kısmen } \\
\text { Bilinçli }\end{array}$ & 40 & 13,5 & 25,6 & 30,6 & 29,5 & 0 & 0 \\
\hline & Naif & 55,6 & 64,6 & 51,9 & 47,1 & 61,4 & & \\
\hline Bilimsel veri ile bilimsel & Bilinçli & 3,4 & 27,1 & 18,8 & 19 & 6,8 & & \\
\hline $\begin{array}{l}\text { kanit aynı şey degildır (Data } \\
\text { are not the same as }\end{array}$ & $\begin{array}{l}\text { Kısmen } \\
\text { Bilinçli }\end{array}$ & 43,9 & 32,3 & 39,8 & 21,5 & 45,5 & 0 & 0 \\
\hline & Naif & 52,7 & 40,6 & 41,4 & 59,5 & 47,7 & & \\
\hline $\begin{array}{lcr}\text { Sorulan } & \text { soru sorgulama } \\
\text { islemine } & \text { rehberlik eder }\end{array}$ & Bilinçli & 11,7 & 30,2 & 14,3 & 24,8 & 9,1 & & \\
\hline (Procedures are guided by & $\begin{array}{l}\text { Kısmen } \\
\text { Bilinçli }\end{array}$ & 31,7 & 21,9 & 33,1 & 14,9 & 18,2 & 0 & $\mathbf{0}$ \\
\hline & Naif & 56,6 & 47,9 & 52,6 & 60,3 & 72,7 & & \\
\hline Araştırma sonuçları toplanan & Bilinçli & 3,9 & 14,6 & 21,8 & 14,9 & 0 & & \\
\hline $\begin{array}{l}\text { verilerle tutarli olmak } \\
\text { zorundadir (Consistent with }\end{array}$ & $\begin{array}{l}\text { Kısmen } \\
\text { Bilinçli }\end{array}$ & 54,1 & 46,9 & 41,4 & 38,8 & 43,2 & 0 & 0 \\
\hline & Naif & 42 & 38,5 & 36,8 & 46,3 & 56,8 & & \\
\hline Çıkarımlar, toplanan verilere & Bilinçli & 1 & 11,5 & 0,8 & 3,3 & 2,3 & & \\
\hline $\begin{array}{lr}\text { ve onceden bilinenlere } \\
\text { dayanilarak yapilır } \\
\text { (Explanations are developed }\end{array}$ & $\begin{array}{l}\text { Kısmen } \\
\text { Bilinçli }\end{array}$ & 22 & 39,6 & 15,8 & 46,3 & 38,6 & 0 & ,015 \\
\hline $\begin{array}{l}\text { from data and already } \\
\text { known conclusions) }\end{array}$ & Naif & 77 & 49 & 83,5 & 50,4 & 59,1 & & \\
\hline
\end{tabular}

* A ve B okulu: Orta Sosyo-ekonomik seviye

** C ve D okulu: Üst Sosyo-eEkonomik seviye

*** E okulu: Alt Sosyo-ekonomik seviye

$\mathrm{P}_{1}$ değeri: 3 grupta yer alan öğrenciler için hesaplanan tekrarlanan Ki-Kare Pearson anlamlılık değeri 
$\mathrm{P}_{2}$ Değeri: Naif grubunda bulunan öğrenciler çıkarıldıktan sonra tekrarlanan Ki-Kare Pearson anlamlılık değeri

\section{Ortaokul Öğrencilerinin Bilimsel Sorgulama Anlayışlarının Sınıf Düzeyine Göre Incelenmesi}

Araştırmaya katılan ortaokul öğrencilerinin bilimsel sorgulama ile ilgili anlayışları bilinçli, kısmen bilinçli ve naif olarak sınıf düzeyine göre kategorizasyonu yapılmış ve yüzde değerleri Tablo 6' da verilmiştir.

Tablo 6. Ortaokul Öğrencilerinin Bilimsel Sorgulama İle İlgili Bilinçli, Kısmen Bilinçli ve Naif Görüsslerinin Sınıf Düzeyine Göre Yüzde Değerleri

\begin{tabular}{|c|c|c|c|c|c|c|}
\hline Bileşenler & $\begin{array}{l}\text { Sinıf } \\
\text { Düzeyi } \\
(5 ., 6 . \text { ve } 7 .)\end{array}$ & $\begin{array}{l}\text { Bilinçli } \\
\%\end{array}$ & $\begin{array}{l}\text { Kısmen } \\
\text { Bilinçli \% }\end{array}$ & $\begin{array}{l}\text { Naif } \\
\%\end{array}$ & $\begin{array}{l}\text { Ki -kare-1 } \\
\text { P }_{1} \text { Değeri* }\end{array}$ & $\begin{array}{l}\text { Ki-kare-2 } \\
\mathrm{P}_{2} \text { Değeri** }\end{array}$ \\
\hline $\begin{array}{l}\text { Bilimsel araştırmaların hepsi bir soru } \\
\text { ile başlar ve her zaman bir hipotez test } \\
\text { etmez (Begins with a question) }\end{array}$ & $\begin{array}{l}5 . \\
6 . \\
7 .\end{array}$ & $\begin{array}{l}2,4 \\
11,9 \\
1,4\end{array}$ & $\begin{array}{l}43 \\
42,1 \\
28,8\end{array}$ & $\begin{array}{l}54,6 \\
46 \\
69,9\end{array}$ & 0,000 & 0,000 \\
\hline $\begin{array}{l}\text { Bütün araştırmalarda takip edilen tek } \\
\text { bir bilimsel yöntem yoktur ( Multiple } \\
\text { methods) }\end{array}$ & $\begin{array}{l}5 . \\
6 . \\
7 .\end{array}$ & $\begin{array}{l}1,6 \\
7,4 \\
1,4\end{array}$ & $\begin{array}{l}52,2 \\
43,6 \\
40,4\end{array}$ & $\begin{array}{l}46,2 \\
49 \\
58,2\end{array}$ & 0,001 & 0,001 \\
\hline $\begin{array}{l}\text { Aynı işlemi yapan bilim insanları aynı } \\
\text { sonuçlara ulaşmayabilirler (Procedures } \\
\text { may not yield the same results) }\end{array}$ & $\begin{array}{l}5 . \\
6 . \\
7 .\end{array}$ & $\begin{array}{l}1,6 \\
8,4 \\
4,8\end{array}$ & $\begin{array}{l}31,1 \\
28,7 \\
27,4\end{array}$ & $\begin{array}{l}67,3 \\
62,9 \\
67,8\end{array}$ & 0,017 & 0,005 \\
\hline $\begin{array}{l}\text { Sorgulama işlemi sonuçlara etki eder } \\
\text { (Procedures influence results) }\end{array}$ & $\begin{array}{l}5 . \\
6 . \\
7 .\end{array}$ & $\begin{array}{l}7,6 \\
23,3 \\
17,1\end{array}$ & $\begin{array}{l}33,1 \\
22,3 \\
34,9\end{array}$ & $\begin{array}{l}59,4 \\
54,5 \\
47,9\end{array}$ & 0,000 & 0,000 \\
\hline $\begin{array}{l}\text { Bilimsel veri ile bilimsel kanıt aynı şey } \\
\text { değildir (Data are not the same as } \\
\text { evidence) }\end{array}$ & $\begin{array}{l}5 . \\
6 . \\
7 .\end{array}$ & $\begin{array}{l}6 \\
23,3 \\
15,1\end{array}$ & $\begin{array}{l}39,4 \\
37,1 \\
31,5\end{array}$ & $\begin{array}{l}54,6 \\
39,6 \\
53,4\end{array}$ & 0,000 & 0,000 \\
\hline $\begin{array}{l}\text { Sorulan soru sorgulama işlemine } \\
\text { rehberlik eder (Procedures are guided } \\
\text { by the question asked) }\end{array}$ & $\begin{array}{l}5 . \\
6 . \\
7 .\end{array}$ & $\begin{array}{l}11,6 \\
23,8 \\
19,9\end{array}$ & $\begin{array}{l}29,1 \\
22,8 \\
25,3\end{array}$ & $\begin{array}{l}59,4 \\
53,5 \\
54,8\end{array}$ & 0,014 & 0,004 \\
\hline $\begin{array}{l}\text { Araştırma sonuçları toplanan verilerle } \\
\text { tutarlı olmak zorundadır (Consistent } \\
\text { with data collected.) }\end{array}$ & $\begin{array}{l}5 . \\
6 . \\
7 .\end{array}$ & $\begin{array}{l}10 \\
13,4 \\
11,6\end{array}$ & $\begin{array}{l}42,2 \\
52 \\
45,2\end{array}$ & $\begin{array}{l}47,8 \\
34,7 \\
43,2\end{array}$ & 0,088 & 0,953 \\
\hline $\begin{array}{l}\text { Çıkarımlar, toplanan verilere ve } \\
\text { önceden bilinenlere dayanılarak yapılır } \\
\text { (Explanations are developed from data } \\
\text { and already known conclusions) }\end{array}$ & $\begin{array}{l}5 . \\
6 . \\
7 .\end{array}$ & $\begin{array}{l}1,6 \\
6,4 \\
1,4\end{array}$ & $\begin{array}{l}29,5 \\
29,2 \\
30,1\end{array}$ & $\begin{array}{l}68,9 \\
64,4 \\
68,5\end{array}$ & 0,031 & 0,011 \\
\hline
\end{tabular}

* $\mathrm{P}_{1}$ değeri: 3 grupta yer alan öğrenciler için hesaplanan tekrarlanan Ki-kare Pearson anlamlılık değeri 
** $\mathrm{P}_{2}$ Değeri: Naif grubunda bulunan öğrenciler çıkarıldıktan sonra tekrarlanan Ki-kare Pearson anlamllık değeri

Tablo 6 incelendiğinde 6.sınıf öğrencilerinin diğer sınıf düzeylerine göre "Bilinçli" düzeyde anlayışa sahip olduğu görülmektedir. Bilinçli anlayış düzeyinin en yüksek olduğu oran "Sorulan soru sorgulama işlemine rehberlik eder" $(\% 23,8)$ olarak tespit edilmiştir. Naif anlayış düzeyinin en yüksek olduğu oran "Çıkarımlar, toplanan verilere ve önceden bilinenlere dayanılarak yapılır" $(\% 64,4)$ bileşeninde tespit edilmiştir.

Kısmen bilinçli anlayış düzeyinin en yüksek olduğu oran 5.sınıf düzeyinde belirlenmiştir. "Bütün araştırmalarda takip edilen tek bir bilimsel yöntem yoktur"(\%52,2) olarak tespit edilmiştir. Naif anlayış düzeyinin en yüksek olduğu oran "Çıkarımlar, toplanan verilere ve önceden bilinenlere dayanılarak yapılır" $(\% 68,9)$ olarak tespit edilmiştir. "Naif" kategoride cevap veren öğrencilerden bir örnek aşağıda ki gibidir:

-Çünkü o yaratıcı bir insan değil ve bencildir. Her şeyin insanoğluna benzemesini, itaat etmesini istiyor (Öğrenci: D.E.5.13).

7.sınıf düzeyinde Bilinçli anlayış düzeyinin en yüksek olduğu oran "Sorulan soru sorgulama işlemine rehberlik eder" $(\% 19,9)$ olarak tespit edilmiştir. Naif anlayış düzeyinin en yüksek olduğu oran "Bilimsel araştırmaların hepsi bir soru ile başlar ve her zaman bir hipotez test etmez" (\%68,5) olarak tespit edilmiştir. Naif" kategoride cevap veren öğrencilerden bir örnek aşağıdaki gibidir:

\section{- Hayır, bilimsel değildir. Deneyler karışımlar için kullanılır(Öğrenci: C.E.6.27).}

Tüm sınıf düzeylerinde Naif düzeyde bulunan öğrencilerin yüzdelerinin genellikle \%50 ve üzerinde olduğu tespit edilmiştir. Bilinçli anlayış düzeyinde ise genel olarak sınıflarda oranın \%20 üzerine çıkmadığı ve oranların birbirine yakın olduğu görülmüştür. Bu oran sınıflar arasında bilinçli anlayışa sahip olmada farklılık olmadığını göstermiştir.

Öğrencilere uygulanan Bilimsel Sorgulamaya İlişkin Görüş anketine göre cinsiyet, sınıf düzeyi ve okula göre sonuçlar incelendiğinde kız öğrencilerin erkek öğrencilere göre daha bilgili olduğu tespit edilmiştir. Sınıf düzeyine göre incelendiğinde 6.sınıf düzeyindeki öğrencilerin diğer sınıf düzeylerine göre bilinçli anlayış düzeyinin daha yüksek olduğu tespit edilmiştir. Fakat bu oran \%20'nin altında kalmıştır. Okula göre incelendiğinde ise özel okul ve devlet okulları arasında "C" olarak kodlanan devlet okulunun daha bilinçli olduğu tespit edilmiştir

\section{Tartışma ve Sonuç}

Fen eğitimiyle ilgili gerçekleştirilen reformlarda sıkça vurgulandığı üzere (Lederman ve diğ. 2019), bilim okuryazarlığının nitelikli bir şekilde sağlanabilmesi öğrencilerin bilimsel sorgulama becerileri ve süreçler hakkında doğru bilgi anlayışlarına sahip olmaları ile doğrudan ilişkilidir. Bilimsel sorgulamaya ilişkin anlayışların gelişimi ise, ilköğretim yıllarında başlamaktadır. Ülkemizde gerçekleştirilen reformlar ve öğretim programındaki yeni yaklaşımlar bağlamında değerlendirildiğinde, 5.sınıf ve sonrasına denk gelen ortaokul kademesi öğrencilerin bilim okuryazarlığ 1 bilgi ve yeterliklerini geliştirdiği (Lederman ve diğ. 2019); ilgi, istek ve yetenekleri doğrultusunda, yükseköğretime ve geleceğe hazırlayan eğitim öğretim sürecinin en önemli kademelerindendir (MEB, 2015). Dolayısıyla bu dönemde gerçekleştirilecek uygulamaların öğrencilerin, hazırbulunuşluk seviyesi, sınıf düzeyi, okul sosyo-ekonomik düzey, 
öğrenme hedefleri vb. ilgili araştırma verileri göz önüne alınarak planlanma yapılması ve niteliğin artırılması gerekmektedir. Bu bağlamda öğrencilerin bilimsel sorgulama anlayışlarını geliştirecek uygulamaların da öğrencilerin mevcut durumları analiz edilerek gerçekleştirilmesi gerekmektedir (Lederman, 2012; Lederman, Bartels, Liu, Jimenez, 2013) Bu nedenle bu çalışmada Türkiye örneklemini temsilen bir ilden alt, orta ve üst sosyo-ekonomik düzeyden seçilen okullarda öğrenim gören 599 ortaokul öğrencisinin bilimsel sorgulama hakkındaki görüşleri, cinsiyetleri ve öğrenim gördükleri okul ve sınıf düzeyi değişkenleriyle ilgili elde edilen verilere dayalı sonuçlar, bileşenlerde gözlemlenen yüksek oranlar doğrultusunda, aşağıda bütüncül olarak sunulmaktadır:

1. Genel değerlendirmede en yüksek oranda bilgili düzeyde görüşe sahip öğrencilerin oranına "araştırma sonuçları toplanan verilerle tutarlı olmalıdır" bilimsel sorgulamanın 6. bileşeninde tespit edilmiştir $(\% 17,7)$. Bitki büyümesi ve verilen 1şık süresini içeren bir kontrollü deneye ilişkin tablo okuma-yorumlama becerilerinin ayrıntılı olarak sorgulandığı soruya, Türk öğrencilerin $\% 26,5$ ile en yüksek düzeyde bilgili görüşlere bu bileşende sahip olduğu Lederman ve diğ. (2019)'nin gerçekleştirdiği çalışma da rapor edilmiştir. Aynı ölçme aracının uygulandığı ve öğrenci sayılarının yüksek olduğu söz konusu iki çalışmada da en yüksek düzeyde bilgili öğrencilere bilimsel sorgulamanın bu bileşeninde rastlanmış olmasının bir nedeninin, sorulan sorunun çoktan seçmeli olmasıyla açıklanabileceği düşünülmektedir. Nitekim, Türkiye'de mevcut merkezi sınavların büyük bir çoğunluğunun halen çoktan seçmeli olarak uygulandığı, öğretmenlerin bu sınavlara yönelik sınıf içi uygulamalarında düzenlemeler yaptığı (MEB, 2010) ve öğrencilerin okulun ilk yıllarından itibaren bu sınavlara ilişkin teknik ve becerilerini geliştirmeye yönelik olarak hazırlandıkları bilinmektedir. Bu durum sonucunda öğrenciler, VASI enstrümanı gibi büyük çoğunluğu öğrencileri derin düşünmeye sevk eden açık uçlu sorulardan oluşan ölçme araçlarına kıyasla, çoktan seçmeli sorularda daha fazla deneyim kazanmaktadırlar (Büyüköztürk, 2016). Dolayısıyla, bilimsel sorgulamanın bu bileşenine yönelik farklı çalışma sonuçlarıyla da tutarlı olarak desteklenen öğrenci başarılarının, ölçme aracının soru tipinden kaynaklandığı sonucuna varılabilir. Bunun yanı sıra Lederman ve diğ. (2019)'nin gerçekleştirdiği çalışmada, Avusturalya, Şili, Çin, Mısır, Avusturya, Güney Afrika, İspanya ve Tayvan gibi ülkelerde de en yüksek oranda bilgili düzeyde öğrencilerin bu bileşende olduğu tespit edilmiştir. $\mathrm{Bu}$ açıdan değerlendirildiğinde bilimsel sorgulamanın bu bileşeninin, birçok farklı ülke öğrencisi tarafından daha iyi anlaşılan veya gelişmeye daha açık bir bileşeni olduğu sonucu çıkarılabilir.

Ayrıca, bilgili öğrencilerin en yüksek yüzdeye sahip olduğu bu bileşende, öğrenciler cinsiyet değişkenine göre incelendiğinde özellikle kız öğrencilerin lehine $(\% 17,1)$ istatistiksel olarak anlamlı $(\mathrm{p}=0.01)$ bir farklılık olduğu; okul türü değişkenine göre bilgili öğrencilerin bu bileşendeki durumları incelendiğinde üst-orta sosyoekonomik düzeyde yer alan $\mathrm{C}, \mathrm{D}$ ve $\mathrm{B}$ okullarında öğrenim gördükleri ve okul türü bağlamında da istatistiksel olarak anlamlı bir fark olduğu $(\mathrm{p}=0.000)$ görülmektedir. Sınıf düzeyi bağlamında ele alındığında ise, bilgili düzeydeki 6 .sınıf öğrencilerin oranının $(\% 13,4)$; 5. $(\% 10,0)$ ve 7 . sinıflara göre $(\% 11,6)$ daha yüksek olduğu ve ancak farkın istatistiksel olarak anlamlı olmadığı $(\mathrm{p}=0.953)$ bulunmuştur. Bu bileşen bağlamında elde edilen sonuçlar Özer \& Doğan (2018)'ın 7.sınıflar, Bolu (2017)'nun 6.sınıflarla yaptığ1 
çalışmaların sonuçlarıyla tutarlılık göstermektedir. Söz konusu araştırmalar, bu bileşene ilişkin öğrenci görüşlerinin yenilikçi fen öğretimi kapsamında gerçekleştirilen uygulamalarla olumlu yönde geliştiğini rapor etmektedir. Bu bağlamda küresel bağlamda da iyi anlaşıldığ çalışmalarda rapor edilmiş ve öğrencilerde neden-sonuç ilişkisi kurma becerilerini de destekleyen bilimsel sorgulamanın bu bileşeninin, 6 ve 7.sınıf öğrencilerinde daha fazla gelişmeye açık olduğu sonucu ortaya çıkmaktadır.

2. Genel değerlendirmede sıralamaya göre ikinci sırada bilgili düzeyde görüşe sahip öğrencilere bilimsel sorgulamanın "aynı süreçleri uygulayan tüm bilim insanları aynı sonuçlara ulaşmayabilirler" 4. bileşeninde rastlanmıştır (\%15,2). Yukarıda bahsedilen 6.bileşenin aksine, bu bileşende Lederman ve diğ. (2019) gerçekleştirdiği çalışmanın sonuçlarında Türk öğrencilerin \%63,8'inin naif düzeyde görüşlere sahip olduğu görülmüştür. Bu bileşenin ölçüldüğü soruda öğrencilere, aynı bilimsel soru ışığında aynı süreçleri uygulayan bilim insanlarının sonuçlarının aynı olup olmayacağına ilişkin açıklama yapmaları ve yanıtlarını gerekçelendirmeleri istenmektedir. Bu bileşen ve ilgili soru aynı zamanda NGSS kapsamında yer alan bilimsel pratiklerden "4-verileri analiz etme ve çıkarımda bulunma" ile de öğrencilerin görüşlerini sorgulamaktadır (Lederman ve diğ., 2014). Sıralamada 6. bileşen sonrası en yüksek düzeyde bilgili öğrencilerin bulunduğu bu bileşende, öğrenciler cinsiyet değişkenine göre incelendiğinde, kız öğrencilerin lehine $(\% 5,7)$ bir fark görülse de bu farkın istatistiksel olarak anlamlı olmadığ ( $\mathrm{p}=0.642)$; ancak okul türü değişkenine göre bilgili öğrencilerin durumları incelendiğinde yine 6 . bileşen sonuçlarına benzer olarak üst-orta sosyoekonomik düzeyde yer alan B ve C okullarında öğrenim gördükleri ve bu farkın istatistiksel olarak anlamlı olduğu $(\mathrm{p}=0.000)$ görülmektedir. Sınıf düzeyi bağlamında ele alındığında da 6.bileşen sonuçlarına benzer olarak bilgili düzeydeki 6.sınıf öğrencilerin $(\% 8,4)$; 5. $(\% 1,6)$ ve 7 . sinıflara göre $(\% 4,8)$ daha yüksek olduğu ve bu farkın istatistiksel olarak anlamlı olduğu $(\mathrm{p}=0.005)$ bulunmuştur.

3. Genel değerlendirmede en yüksek oranda kısmen bilinçli düzeyinde görüşe sahip öğrencilere bilimsel sorgulamanın "bilimsel araştırmaları gerçekleştirmek için izlenecek tek tip bir yol yoktur" 2. bileşeninde gözlemlenmiştir $(\% 46,4)$. Bu bileşenin ölçüldüğü alt sorularda kuşlarla ilgilenen bir bilim insanı örneği üzerinden, olayda anlatılan bilim insanının gerçekleştirdiği sürecin bir deney olup olmadığı ve bu tür süreçlerde izlenen genel tek tip bir yol olup olmadığı sorulmaktadır. Bu bileşen ve ilgili soru aynı zamanda NGSS kapsamında yer alan bilimsel pratiklerden "1-soru sorma ve problemi belirleme" ile "3-araştırma tasarlama ve gerçekleştirme" ile de öğrencilerin görüşlerini sorgulamaktadır. En yüksek oranda kısmen bilinçli düzeyde öğrencilerin bulunduğu bu bileşende, öğrenciler cinsiyet değişkenine göre incelendiğinde, k1z öğrencilerin lehine $(\% 5,4)$ istatistiksel olarak anlamlı bir farklılık olduğu $(\mathrm{p}=0.026)$; okul türü değişkenine göre en iyi sonuçların üst-orta sosyoekonomik düzeyde yer alan $\mathrm{B}$ devlet okulunda öğrenim gören öğrenciler oldukları $(\% 10,4)$ ve sonucun istatistiksel olarak anlamlı olduğu $(\mathrm{p}=0.033)$ görülmektedir. Sınıf düzeyi bağlamında ele alındığında, yine üstte verilen sonuçlara benzer olarak 6.sınıf öğrencilerinin $(\% 7,4), 5$. $(\% 1,6)$ ve 7 . sinıflara göre $(\% 1,4)$ daha yüksek olduğu ve sınıf düzeyinin istatistiksel olarak anlamlı olduğu $(\mathrm{p}=0.001)$ sonucuna varılmıştır. 
4. Genel değerlendirmede sıralamaya göre ikinci sırada kısmen bilinçli düzeyinde görüşe sahip öğrencilere bilimsel sorgulamanın "bilimsel veri ve bilimsel kanitlar ayn değildir" 7. bileşeninde tespit edilmiştir $(\% 46,2)$. Bu bileşenin ölçüldüğü soruda, bilimsel veri ve delilin öğrenciler için ne anlam ifade ettiğini açıklamaları beklenmektedir. Bu bileşen ve ilgili soru aynı zamanda NGSS kapsamında yer alan bilimsel pratiklerden "7-delil temelli tartışmalara dahil olma" ve "8-bilgiyi elde etme, değerlendirme ve iletişim kurma" ile ilgili de öğrencilerin görüşlerini sorgulamaktadır (Lederman ve diğ., 2014). En yüksek kısmen bilinçli düzeyde bilgili öğrencilerin bulunduğu bu bileşende, öğrenciler cinsiyet değişkenine göre incelendiğinde özellikle kız öğrencilerin lehine (\%20) anlamlı bir farklılık olduğu ( $\mathrm{p}=0.003)$; okul türü değişkenine göre öğrencilerin bu bileşendeki durumları incelendiğinde en iyi sonuçların üst-orta sosyo-ekonomik düzeyde yer alan $\mathrm{B}$, D ve $\mathrm{C}$ okullarında öğrenim gördükleri ve sonuçların istatistiksel olarak anlamlı olduğu $(\mathrm{p}=0.000)$ görülmektedir. Sinıf düzeyi bağlamında ele alındığında, yine üstte verilen sonuçlara benzer olarak bilinçli düzeydeki $6 . \sin ı$ öğrencilerin $(\% 23,3)$; 5. (\%6) ve 7. sinıflara göre $(\% 15,1)$ daha yüksek olduğu ve farkın istatiksel olarak anlamlı olduğu $(\mathrm{p}=0.000)$ bulunmuştur.

5. Genel değerlendirmede en yüksek oranda naif düzeyinde görüşe sahip öğrencilere bilimsel sorgulamanın "açıklamalar, elde edilen veriler ve mevcut bilgilerin birlikte kullanılmasıyla geliştirilir" 8. bileşeninde görülmüştür $(\% 67,3)$. Bu bileşenin ölçüldüğü 7. soru $\mathrm{a}$ ve $\mathrm{b}$ şıklarında, öğrencilere verilere dayalı çıkarımlar hakkında paleontologların çalışmaları sonucunda yerin altından çıkardıkları dinozor kemikleri ve diğer vücut kalıntılarını birleştirirken hangi bilgilerinden yararlanarak günümüzde karşılaşılan dinozor modellerini oluşturdukları sorulmaktadır. Bu bileşen ve ilgili sorular aynı zamanda NGSS kapsamında yer alan bilimsel pratiklerden "6-verilere dayalı açıklamalar geliştirme ve çözümler üretme" ile ilgili de öğrencilerin görüşlerini değerlendirmektedir (Lederman ve diğ. 2014). En yüksek düzeyde naif öğrencilerin bulunduğu bilimsel sorgulamanın bu bileşeninde, öğrencilerin cinsiyetleri arasında istatistiksel olarak anlamlı bir fark bulunmamaktadır $(\mathrm{p}=0.149)$. Okul türü değişkenine göre bu bileşendeki durum incelendiğinde en iyi sonuçların üst-orta sosyoekonomik düzeyde yer alan B okulu lehine istatistiksel olarak anlamlı bir fark ortaya koymuştur $(\mathrm{p}=0.015)$. Sınıf düzeyleri bağlamında incelendiğinde, 6.sınıf lehine anlamlı bir fark olduğu görülmektedir $(\mathrm{p}=0.011)$. Sonuçlar doğrultusunda ortaokul öğrencilerinin büyük bir çoğunluğunun bilimsel olarak elde edilen veriler ve mevcut bilgilerin birlikte kullanılmasıyla geliştirilen açıklamaların önemi hakkında yetersiz bilgilere sahip olduğu sonucu çıkarılabilir. Bilindiği üzere PISA gibi uluslararası standart sınavlarda da öğrencilerde ölçülmek istenen yeterliliklerden biri de 'bilimsel olguları açıklama' yeterliliğidir. Türkiye örneklemi bağlamında değerlendirildiğinde PISA sınavlarında bu kriterde ülkemiz öğrencilerinin istenen seviyede başarılı olmadıkları göze çarpmaktadır (Taş, Arıcı, Özarkan ve Özgürlük, 2016). Öğrencilerin bilimsel açılamalar ortaya koymadaki yetersizliklerinin nedenleri olarak, uzun yıllardır eğitim sisteminde ölçme ve yerleştirme aracı olarak kullanılan çoktan seçmeli sorulara dayalı sınavlar, kısa cevaplı veya açıklama gerektirmeyen değerlendirme yöntemleri, alternatif ölçme değerlendirme yöntemlerinin yeterince kullanıl(a)maması, kavramların derinlemesine öğrenilememesi, sorgulama becerilerinin yetersiz olması vb. çeşitli sebepler gösterilebilir (Karaaslan \& 
Ayas, 2017). Bu beceri ve bileşen altındaki görüşlerin geliştirilmesi, öğrencilerin bireysel veya grup olarak elde ettikleri veri ve bilgilerinden çıkarımlar yaptıkları, açıklamalar geliştirdikleri sorgulamaya dayalı sınıf içi uygulamaları gerektirmektedir. Ancak bu tür uygulamalarda geliştirilen açıklamaların niteliği ve temellerinin veribilgilere dayandırılması konusunda öğretmenlerin süreçteki rolleri oldukça önemlidir. Ayrıca öğrencilerin geliştirecekleri açıklamaları birbirlerinin açıklamalarıyla karşılaştırmalı olarak da değerlendirerek süreçte sürekli olarak yansıtıcı olmaları açıklama becerilerinin gelişimine destek olabilir. Bu tür öğrenme ortamları da fen öğretimi kapsamında argümantasyon (Erduran \& Jimenez-Aleixandre, 2008), kanittemelli uygulamalar (evidence-based practices) (Aikenhead, 2006) ve bilimsel pratiklere dayalı fen öğretimi gibi farklı yaklaşımların sürece dahil edilmesiyle gerçekleştirilebilir. Dolayısıyla öğrencilerin bilimsel olgulara bilim insanlarının yaptığına benzer olarak açıklama geliştirme süreçlerini fen öğretiminin bir parçası olarak sürekli yaşamaları bilimsel sorgulamanın bu bileşeni hakkında daha bilgili görüşlere sahip olmalarını sağlayabilir.

6. Genel değerlendirmede sıralamaya göre ikinci sırada en yüksek oranda naif görüşe sahip öğrencilere bilimsel sorgulamanın "bilimsel araştırma soruları süreçlere rehberlik eder" 3. bileşeninde rastlanmıştır $(\% 65,9)$. Bu bileşenin ölçüldüğü soruda öğrencilere, iki farklı araştırma grubunun araştırma sorularındaki eksikliklerini belirlemeleri amaçlanmakta ve araştırma süreçlerinin gereklilikleri ile ilgili bilgileri yoklanmaktadır. Öğrencilerden açık uçlu olarak hangi araştırma grubunun sorusunun daha iyi olduğunu belirlemeleri istenmekte ve süreçlerinin birbirilerine göre avantajlarının açıklayarak değerlendirilmesi beklenmektedir. Bu bileşen ve ilgili soru aynı zamanda NGSS kapsamında yer alan bilimsel pratiklerden "1-soru sorma ve araştırma yapma ve 4-verileri analiz etme ve çıkarımda bulunma" ile de öğrencilerin görüşlerini sorgulamaktadır (Lederman ve diğ., 2014). Siralamaya göre ikinci sırada en yüksek oranda naif düzeyde öğrencilerin bulunduğu bu bileşende, öğrenciler cinsiyet değişkenine göre incelendiğinde kız öğrencilerin lehine $(\% 21,6)$ anlamlı bir farklılık olduğu ( $\mathrm{p}=0,006)$; okul türü değişkenine göre en iyi sonuçların üst-orta sosyoekonomik düzeyde yer alan $\mathrm{B}$ ve $\mathrm{D}$ okullarında öğrenim gören öğrenciler oldukları görülmektedir. Sınıf düzeyi bağlamında ele alındığında, bilinçli ve kısmen bilinçli sonuçlarında da rastlandığı üzere 6.sınıf öğrencilerinin $(\% 23,8) ; 5$. $(\% 11,6)$ ve 7 . sınıflara göre $(\% 19,9)$ daha yüksek olduğu bulunmuştur. Elde edilen sonuçlar doğrultusunda ortaokul öğrencilerinin büyük bir çoğunluğunun araştırma sorularının niteliğini ve içerdiği prosedürleri birbirlerine göre değerlendirmede yetersiz olduğu görülmektedir. Özellikle 2005, 2013 ve 2018 yıllarında gerçekleştirilen Fen Bilimleri dersi öğretim programı reformlarında da sıkça vurgulandığı üzere, sorgulamaya dayalı öğretimde öğrencilerin araştırma soruları oluşturarak, veri toplamaları ve çıkarımlarda bulunmaları hedeflenmektedir (MEB, 2005; 2013; 2018). Karşılaşılan bu sonuç okul farklılıkları bağlamında da değerlendirildiğinde ise, özellikle alt-orta farklı sosyoekonomik düzeylerde yer alan A ve E gibi okullarda da bu hedefin gerçekleştirilmesine yönelik öğretim programıyla uyumlu uygulamaların istenen şekilde çeşitli sosyo-ekonomik farklı1ıklar nedeniyle başarıya ulaşamadığı sonucu çıkarılabilir. Bilimsel sorgulamaya dayalı görüşlerin bu bileşeni özelinde, özellikle öğretmenlerin öğrencileri araştırma- 
sorgulama faaliyetlerine yönlendirecek süreçlere öğretim süreçlerinde daha fazla yer vererek, öğrencilerin bu süreçlere ilişkin olarak doğrudan yansıtıcı yaklaşım kapsamında yansıtma yapmaları sağlanmalıdır. Bu çıkarımı doğrular nitelikteki çalışmalara Özer \& Doğan (2018), Leblebicioğlu vd. (2017) ve Bolu (2017)'nin gerçekleştirdiği yarı deneysel çalışmaların sonuçlarında rastlanmıştır. Söz konusu çalışmalar, bu bileşene ilişkin görüşlerin yenilikçi fen öğretimi kapsamında gerçekleştirilen uygulamalarla olumlu yönde geliştiğini rapor etmektedir. $\mathrm{Bu}$ çalışmalarda ortak olarak bu bileşenin ortaokul öğrencilerinde kolay gelişmeye açık bileşenlerden biri olduğu sonucuna varılmış olması, naif düzeydeki öğrencilerin çeşitli formal ve informal fen etkinlikleriyle desteklenmesiyle, bilimsel araştırmaların sorular ile şekillendirildiği anlayışı hakkında daha doğru ve bilgili anlayışlara sahip olmalarını sağlayabilir. Nitekim alan yazında da sıkça vurgulandığı üzere, sorgulama süreçlerinin hem öğrenciler hem de öğretmenler tarafından açık bir şekilde sürekli olarak vurgulanması öğrencilerin bilimsel sorgulama hakkındaki görüşlerinin gelişmesini desteklemektedir (Abd-El-Khalick \& Lederman, 2000; Bell, Blair, Crawford ve Lederman, 2003; Haefner \& Zembal-Saul, 2004; Schwartz, Lederman ve Crawford, 2004).

Sonuç olarak, incelenen örneklem bağlamında elde edilen veriler ortaokul öğrencilerinin bilimsel sorgulama hakkındaki görüşlerinin daha çok naif ve kısmen bilinçli düzeyinde olduğunu ortaya çıkarmıştır. Bu sonuçların Lederman vd. (2019) tarafından gerçekleştirilen çalışmanın Türkiye örneklemi sonuçlarıyla, Doğan \& Özer (2018), Leblebicioğlu ve diğ. (2017), Bolu (2017) ve Senler (2015)'in gerçekleştirdiği çalışmaların sonuçlarıyla tutarlı olduğu görülmüştür. $\mathrm{Bu}$ çalışmalar bağlamında, Türkiye'deki ortaokul öğrencilerinin bilimsel sorgulama anlayışlarının yetersiz düzeyde olduğu görülmektedir. Çalışmanın sonuçları derinlemesine incelendiğinde ise, bilinçli düzeyde görüşlere sahip olan ortaokul öğrencilerinin büyük bir kısmını, özellikle üst-orta sosyoekonomik düzey okulların 6. sınıflarında öğrenim gören öğrencilerin oluşturduğu görülmüştür. Buradan da, öğrencilerin bilimsel sorgulama hakkında sahip oldukları bilinçli görüşlerinin, eğitim gördükleri okul türü -dolayısıylaailelerinin sosyo-ekonomik düzeyleri ve sınıf düzeyi gibi değişkenlerle açıklanabildiği sonucu çıkarılabilir.

Öğrencilerin naif düzeyde görüşlere sahip oldukları durumlarda ise cinsiyet, sınıf düzeyi ve okul türü değişkenleri bağlamlarında anlamlı örüntülerin ortaya çıkmadığı görülmüştür. Özellikle 6.sınıf seviyesinin bu görüşlerin gelişmeye en uygun sinıf düzeyi olduğu sonucundan yola çıkılarak, ortaokul 7. ve 8. sınıflarda öğrencilerin bu görüşlerini kalıcı hale getirmeye yönelik sorgulama temelli çağdaş, yenilikçi uygulamalarla zenginleştirilmiş öğrenme ortamlarına daha fazla yer verilmesi önerilmektedir. Ayrıca öğrencilerin bilimsel sorgulama hakkındaki görüşlerini geliştirmeye katkı sağlayacak çeşitli deneysel/yarı deneysel desen araştırma faaliyetleri ve projelerin sayısı arttırılmalı, öğrencilerin bilimi yaparak-yaşayarak öğrendikleri doğa/bilim kampları ve farklı informal öğrenme ortamlarına katılımları teşvik edilmelidir. Bunların yanı sıra, özellikle sosyoekonomik düzey değişkeninin öğrencilerin bilimsel sorgulamaya ilişkin görüşlerini bu denli etkileme potansiyeli üzerindeki durumu değerlendirildiğinde, düşük ve orta sosyo ekonomik düzeyde yer alan okulların çeşitli seçmeli ders veya müfredat dışı özel sorgulama etkinliklerine programlarında daha fazla yer vermeleri konusunda teşvik edilmeleri önerilmektedir. 


\section{Teşekkür}

$\mathrm{Bu}$ çalışma Bolu Abant İzzet Baysal Üniversitesi Bilimsel Araştırmalar Proje Ofisi'nce desteklenen 2017.02.04.1184 no'lu proje kapsamında gerçekleştirilmiştir.

Çalışmanın veri toplama sürecine gönüllü katılarak öğrencilerine özveriyle anketlerin uygulanmasını sağlayan, sınıflarında araştırmacıların uygulama yapmasına izin vererek araştırma sürecine destek veren Fen Bilimleri öğretmenleri Bahar Varilci, Cenk Kulaç, Ebru Özşahin, Ertan Eroğlu, Hande Başkalyoncu, Hayrettin Emen, Yasemin Bolu, Yeliz Yamak ve Müdür Yardımcıları Hayrullah Yılmaz, İsmail Türk, Kasım Kaya, Serdar Koçak'a, katkılarından dolayı teşekkür ederiz.

Ortaokul Öğrencilerinin Bilimsel Sorgulama Görüşleri: Cinsiyet, Sınıf Düzeyi ve Okul Türü Değişkenlerinin İncelenmesi başlıklı çalışmanın yazım sürecinde bilimsel, etik ve alıntı kurallarına uyulmuş; toplanan veriler üzerinde herhangi bir tahrifat yapılmamış, karşılaşılacak tüm etik ihlallerde "Pamukkale Üniversitesi Eğitim Fakültesi Dergisi Yayın Kurulunun" hiçbir sorumluluğunun olmadığı, tüm sorumluluğun Sorumlu Yazara ait olduğu ve bu 
çalışmanın herhangi başka bir akademik yayın ortamına değerlendirme için gönderilmemiş olduğunu taahhüt ederim.

\section{Kaynakça}

Abd-El-Khalick, F., \& Lederman, N. G. (2000). Improving science teachers' conceptions of nature of science: A critical review of the literature. International Journal of Science Education, $22,665-701$

Aikenhead, G. S. (2006). Science education for everyday life: Evidence-based practice. New York: Teachers College Press.

Akerson, V. L., \& Hanuscin, D. L. (2007). Teaching nature of science through inquiry: Results of a 3-year professional development program. Journal of Research in Science Teaching, 44(5), 653680.

American Association for the Advancement of Science [AAAS]. (1993). Benchmarks for science literacy. NewYork: Oxford University Press.

Ann Haefner, L., \& Zembal-Saul, C. (2004). Learning by doing? Prospective elementary teachers' developing understandings of scientific inquiry and science teaching and learning. International Journal of Science Education, 26(13), 1653-1674.

Araceli Ruiz-Primo, M., \& Furtak, E. M. (2006). Informal formative assessment and scientific inquiry: Exploring teachers' practices and student learning. Educational Assessment, 11(3-4), 237-263.

Aydeniz, M., Baksa, K., \& Skinner, J. (2011). Understanding the impact of an apprenticeship-based scientific research program on high school students' understanding of scientific inquiry. Journal of Science Education and Technology, 20(4), 403-421.

Baykar, H., Yakar, Z., Liu, S. Y. (2018). Preservice science teachers' views about scientific inquiry. European Journal of Education Studies, 4(10), 128-143.

Bell, R. L., Blair, L. M., Crawford, B. A., \& Lederman, N. G. (2003). Just do it? Impact of a science apprenticeship program on high school students' understandings of the nature of science and scientific inquiry. Journal of Research in Science Teaching, 40(5), 487-509.

Bolu, Y. (2017). 6.Sinıf ögrrencilerinin bilimsel sorgulama, yaratıcılık, fen başarısı ve tutumlarına modellemeye dayalı fen ögretiminin etkisi. Yayımlanmamış Yüksek Lisans Tezi, Abant İzzet baysal Üniversitesi Eğitim Bilimleri Enstitüsü, Bolu.

Büyüköztürk, Ş. (2016). Sınavlar üzerine düşünceler. Kalem Eğitim ve İnsani Bilimler Dergisi 6(2), 345356.

Çiğdemoğlu, C. ve Köseoğlu, F. (2019). Improving science teachers' views about scientific inquiry. Science \& Education, 28, 439-469.

Crawford, B. (2014). From inquiry to scientific practices in the science classroom. In N. Lederman \& S. Abell (Eds.), Handbook of research on science education, vol. II (pp. 515-544). New York: Taylor and Francis Group.

Donohue, K., Buck, G. A., ve Akerson, V. (2020). Where's the science? Exploring a new science teacher educator's theoretical and practical understandings of scientific inquiry. International Journal of Research in Education and Science (IJRES), 6(1), 1-13.

DeBoer, G. E. (2000). Scientific literacy: Another look at its historical and contemporary meanings and its relationship to science education reform. Journal of Research in Science Teaching, 37(6), 582-601.

Doğan, N. \& Özer, F. (2018). Bölüm 7: Fen bilimlerinde bilimin doğası ve öğretimi. Tekbıyık, A. \& Çakmakçı, G. (ed.). Fen Bilimleri Öğretimi ve STEM Etkinlikleri (ss.175-210). Nobel Akademik Yayıncılık: Ankara. ISBN:978-605-7928-31-3.

Dogan, N. (2017). Blending problem based learning and history of science approaches 
to enhance views about scientific inquiry: New wine in an old bottle. Journal of Education and Training Studies, 5(10), 99-112.

Dogan, N., Cakmakci, G., Irez, S., Yalaki, Y., Erdas, E., Kaya, G., Özer, F., Han, Tosunoğlu, Ç., Altıner, Z.B., Bala, V.G., Ertuğrul, G., Şardağ, M., Köylü, N.Z., \& Gunsever, G., (2016). Etkinliklerle bilimin doğasının ögretimi. Y. Yalaki (Ed.), (Genişletilmiş 2. Baskı). Ankara: Pegem Akademi Yayınc1lik.e-ISBN:978-605-318-3976 http://www.pegem.net/dosyalar/dokuman/191701_ekitap.pdf

Erduran, S. \& Jimenez-Aleixandre, M. P. (2008). Argumentation in science education: perspectives from classroom-based research. Dordrecht, Netherlands: Springer.

Furtak, E. M. (2006). The problem with answers: An exploration of guided scientific inquiry teaching. Science Education, 90(3), 453-467.

Gaigher, E., Lederman, N., \& Lederman, J. (2014). Knowledge about Inquiry: A study in South African high schools. International Journal of Science Education, 36(18), 3125-3147.

Haefner, L. A., \& Zembal-Saul, C. (2004). Learning by doing? Prospective elementary teachers' understandings of scientific inquiry and science teaching and learning. International Journal of Science Education, 26, 1653-1674.

Han-Tosunoglu, C., Dogan, O. K., Yalaki, Y., Cakir, M., ve İrez, S. (2017, April). Turkish 7th Grade Students' Views about Scientific Inquiry. In J. Lederman \& N. G. Lederman (Chair), International Collaborative Investigation of Beginning Seventh Grade Students' Understandings of Scientific Inquiry. Symposium conducted at the meeting of National Association for Research in Science Teaching. Chicago,IL,USA.

Hamed, S., Rivero, A., \& Jimenez, J. (2018). Views about scientific inquiry (VASI): the case of Spain. Ensenanza de las Ciencias, (Extra), 3561-3568

Karaaslan, E. H. \& Ayas, A. (2017). Fen eğitiminde 'bilimsel açıklama' ve önemi. Ahi Evran Üniversitesi Kırşehir Eğitim Fakültesi Dergisi (KEFAD) 17,3,101-120.

Karasar, N. (2018). Bilimsel araştırma yöntemi: Kavramlar, ilkeler ve teknikler. 33.Bask1. Ankara: Nobel Akademik Yayıncılık.

Karışan, D., Bilican, K., \& Şenler, B. (2017). Bilimsel sorgulama hakkında görüş anketi: Türkçeye uyarlama, geçerlik ve güvenirlik çalışması. Inönü Üniversitesi Eğitim Fakültesi Dergisi, 18(1), 326-343.

Leblebicioglu, G., Metin, D., Capkinoglu, E., Cetin, P. S., Dogan, E. E., \& Schwartz, R. (2017). Changes in students' views about nature of scientific inquiry at a science camp. Science \& Education, 26(7-9), 889-917.

Lederman, J. S. (2009). Teaching scientific inquiry: Exploration, directed, guided, and opened-ended levels. National geographic science: Best practices and research base, 8-20. Retrieved from http://bit. ly/2LMIrjR

Lederman, N.G. (2012). Development of a valid and relliable protocol fort he assessement of early childhood students' conception of nature of science and scientific inquiry. Paper presented at the meeting of the National Association for Research in Science Teaching (NARST), Indianapolis, IN,USA

Lederman, J. S., Bartels, S. L, Liu, C., ve Jimenez, J. (2013). Teaching nature of science and scientific inquiry to diverse classess of early primary level students. Paper presented at the meeting of the National Association for Research in Science Teaching (NARST), San Juan, PR,USA.

Lederman, J. S., Lederman, N.G., Bartos, S. A., Bartels, S. L, Meyer, A. A., \& Schwartz, R. S. (2014). Meaningful assessment of learners' understandings about scientific inquiry - the views about scientific inquiry (VASI) questionnaire. Journal of Research in Science Teaching, 51(1) 65-83.

Lederman, J.S., Lederman, N.G., Bartels, S., Jimenez, J., Akubo, M., vd. (2019). An international 
collaborative investigation of beginning seventh grade students' understandings of scientific inquiry: Establishing a baseline. Journal of Research in Science Teaching. DOI: 10.1002/tea.21512.

Lotter, C., Harwood, W. S., \& Bonner, J. J. (2006). Overcoming a learning bottleneck: Inquiry professional development for secondary science teachers. Journal of Science Teacher Education, 17(3), 185-216.

Lotter, C., Harwood, W. S., \& Bonner, J. J. (2007). The influence of core teaching conceptions on teachers' use of inquiry teaching practices. Journal of Research in Science Teaching, 44(9), 1318-1347.

Manlove, S., Lazonder, A. W., \& de Jong, T. (2006). Regulative support for collaborative scientific inquiry learning. Journal of Computer Assisted Learning, 22(2), 87-98.

Metz, K. E. (2004). Children's understanding of scientific inquiry: Their conceptualization of uncertainty in investigations of their own design. Cognitionand Instruction, 22(2), 219-290.

Milli Eğitim Bakanlığı (2005). İlkögretim fen ve teknoloji dersi ögretim programı. Ankara: Milli Eğ̈tim Basımevi.

Milli Eğitim Bakanlığı Eğitimi Araştırma ve Geliştirme Dairesi Başkanlı̆̆ (2010). Seviye belirleme sınavının değerlendirilmesi araştırması ön raporu.

Milli Eğitim Bakanlığı (2013). Fen bilimleri dersi (3, 4, 5, 6, 7 ve 8. sinıflar) öğretim programı. Ankara: Milli Eğtim Basımevi.

Milli Eğitim Bakanlığı (MEB, 2015). Türk Ĕgitim Sistemi ve Ortaöğretim. Ortaöğretim Genel Müdürlügü̈. Ankara. ISBN 978-975-11-3898-9

http://ogm.meb.gov.tr/meb_iys_dosyalar/2017_06/13153013_TES_ve_ORTAYYRETYM_son1 0_2.pdf

Milli Eğitim Bakanlığı (2018). Fen bilimleri dersi (3, 4, 5, 6, 7 ve 8. sinıflar) ögretim programı. Ankara: Milli Eğitim Basımevi.

National Research Council [NRC]. (2000). Inquiry and the national science education standards. Washington, DC: National Academy Press.

National Research Council [NRC]. (2011). A framework for K-12 science education: Practices, crosscutting concepts, and core ideas. Washington, DC: National Academy Press.

NGSS Lead States. (2013). Next generation science standards: For states, by states. Washington, DC: The National Academy Press.

Osborne, J. (2014). Scientific practices and inquiry in the science classroom. In N. Lederman \& S. Abell (Eds.), The handbook of research on science education, vol. II (pp. 579-599). New York: Taylor and Frances Group.

Özer, F. \& Doğan, N. (2018). Investigation of the impact of problem-based learning on Turkish middle school students' essential skills about $21^{\text {st }}$ Century. NARST (National Association for Research in Science Teaching) Annual Conference 2018, Atlanta, GA, USA

Roberts, D. A. (2008). Scientific literacy/science literacy. in S. K. Abell \& N. G. Lederman (Eds.), Handbook of research on science education (pp. 729-780). Mahwah, NJ: Lawrence Erlbaum Associates.

Roberts, P., Priest, H., \& Traynor, M. (2006). Reliability and validity in research. Nursing standard, 20 , (44). 41-45.

Roth, W. M., McGinn, M. K., \& Bowen, G. M. (1998). How prepared are preservice teachers to teach scientific inquiry? Levels of performance in scientific representation practices. Journal of Science Teacher Education, 9(1), 25-48.

Ruiz-Primo, M. A., \& Furtak, E. M. (2006a). Exploring teachers' informal formative assessment practices and students' understanding in the context of scientific inquiry. Journal of Research in Science Teaching, 44(1), 57-84. 
Ruiz-Primo, M. A., \& Furtak, E. M. (2006b). Informal formative assessment and scientific inquiry: Exploring teachers' practices and student learning. Educational Assessment, 11(3-4), 237-263.

Yıldırım, A., \& Şimşek, H. (2006). Sosyal bilimlerde nitel araştırma yöntemleri. Ankara: Seçkin Yayıncilik.

Schwartz, R. S., Lederman, N. G., \& Crawford, B. A. (2004). Developing views of nature of science in an authentic context: An explicit approach to bridging the gap between nature of science and scientific inquiry. Science Education, 88(2), 610-645.

Schwartz, R. S., Lederman, N. G., ve Lederman, J. S. (2008). An instrument to assess views of scientific inquiry: the VOSI questionnaire, Paper presented at the meeting of the National Association for Research in Science Teaching (NARST), Baltimore, MD,USA.

Senler, B. (2015). Middle school students' views of scientific inquiry: An international comparative study. Science Education International, 26(2), 166-179.

Taş, U. E., Arıcı, Ö., Ozarkan, H. B. \& Özgürlük, B. (2016). Uluslararası öğrenci değerlendirme programı-PISA 2015 Ulusal Raporu. Ankara: MEB Yayınları.

Wee, B., Fast, J., Shepardson, D., Harbor, J., \& Boone, W. (2004). Students' perceptions of environmental-based inquiry experiences. School Science And Mathematics, 104(3), 112-118. 


\section{Extended Abstract}

\section{Introduction}

The term of scientific literacy refers to the knowledge about what is science, to understand its' limitations, how the scientific knowledge is produced, being aware of its' potential effects on technology and society or vice versa, and being able to use that knowledge in basis daily decision-making processes. In sum, the term defines what the public should know about science in order to make their life effective by leading them to make informed decisions (NRC, 1996; DeBoer, 2000; Roberts, 2008). In line with these definitions, science literacy is one of the most important concepts of $21^{\text {st }}$ century science education and its most integral components are "subject-matter knowledge", "nature of science views" and "scientific inquiry" (Lederman, 2009). Scientific inquiry (SI) basically refers to the combination of having science process skills, understandings about how scientists produce scientific knowledge, having subject matter knowledge, creativity and critical thinking in problem solutions (Lederman et al. 2019). The importance of gradual development of scientific inquiry skills and understandings of students is emphasized in both international and national reform documents as one of the important objectives of science education (Benchmarks for Science Literacy, AAAS, 1993; A Framework for K-12 Science Education: Practices, Crosscutting Concepts, and Core Ideas, National Research Council [NRC], 2011; Ministry of National Education, 2018). It is mostly higlighted in the literature that that students who have adequate understanding about SI will develop the inquiry skills concurrently. Yet, gradual development of inquiry skills and understanding require a careful planning and implementation of inquiry-based strategies and classroom practices. And before planning and implementing the inquiry based strategies there is a need for descriptive studies. Therefore in order to plan the design of the learning environment, the quality of instruction and the content of the practices, primarily there is a need for descriptive studies that examines the current state of students' SI views, apart from the experimental and quasi-experimental studies which mainly aim to increase the quality of inquiry-based teaching practices or utilizing the genuine classroom practices to support the development of those views. In addition to this, revealing Turkish middle school students' SI views is considered crucial in terms of Turkey's sample and its' genuine variables and provide the general insight for scholars in planning the practices that would support the development of these views. Thus, the aim of this study is to descriptively examine and to present the SI views of a total of $n=5995^{\text {th }}, 6^{\text {th }}$ and $7^{\text {th }}$ grade students studying at five different schools with different socio-economic states in Turkey.

\section{Methodology}

In order to have a general insight about the current state of Turkish middle school students' SI views, the design is designated as descriptive. Thus, primary data source of the study is the written and oral responses of $5^{\text {th }}, 6^{\text {th }}, 7^{\text {th }}$ grade students gathered from the Views About Scientific Inquiry (VASI), developed by Lederman et al. (2014), open-ended questionnaire. The data was 
collected from 5 different schools (4 state schools, 1 private school) located in a small city in Western Black Sea region of Turkey. Schools' socioeconomic states are different from each other and the participants were the 599 (315 female, 284 male) $5^{\text {th }}, 6^{\text {th }}, 7^{\text {th }}$ grade students. The responses of the students were analyzed through content analysis by three different researchers and the inter-rater reliability among them was calculated 0,95 . The rubrics developed by Lederman et al. (2014) were used for coding, then the responses were categorically grouped as "naïve-1", "eclectic-2", "informed-3". Descriptive statistics and Pearson Chi-Square Test were run to reveal the group's understanding in terms of different aspects of SI.

\section{Results and Discussion}

The results showed that $5^{\text {th }}, 6^{\text {th }}, 7^{\text {th }}$ graders' understandings about all aspects of scientific inquiry were scattered mostly in naïve and eclectic categories. These results are consistent with the Turkey's findings of Lederman et al. (2019)'s study that examined the $7^{\text {th }}$ graders' understanding of scientific inquiry in 18 countries as well as findings of Özer \& Doğan (2018), Leblebicioğlu et al. (2017), Bolu (2017) and Şenler (2015). In this vein, it can be concluded that the middle school students' understanding of scientific inquiry are inadequate. In terms of gender, grade level and school type variables, there were no significant patterns in cases where the students hold naive understandings. However, in depth analysis showed that few students who holds informed views (\%20) about SI are the $6^{\text {th }}$ grade students studying at upper-middle socioeconomic state schools. In other words, the adequate understandings of the students about the scientific inquiry can be explained by the variables such as the type of school in which they study at and the socio-economic levels of their families and the grade level. In particular, it is suggested that the 6th grade level science instruction should be supported with more appropriate inquiry-based practices, since the findings resulted that this grade is the most appropriate grade in cases where students are informed. In addition, the schools which have the low socioeconomic states should be encouraged to include more extra-curricular specific inquirybased activities to their program since the socioeconomic level may potentially have an impact on the understandings of SI. 